\title{
A JurisprudênCia do Tribunal de Justiça do Distrito Federal em Ações de Medicamentos
}

\author{
THE JURISPRUDENCE OF THE DISTRITO FEDERAL (BRAZIL) \\ COURT OF JUSTICE ON MEDICAMENTS LAWSUITS
}

Luiz Carlos Romero ${ }^{(*)}$

\section{RESUMO}

Objetivo: descrever a conformação e as características da jurisprudência do Tribunal de Justiça do Distrito Federal (TJDF), Brasil, em relação a ações de medicamentos. Método: pesquisa documental na base de dados do TJDF dos acórdãos julgados por essa corte no período de 2001 a 2005, referente a ações que pleiteavam o fornecimento de medicamentos pela Secretaria de Saúde do Distrito Federal (SESDF). Resultados: (1) reconhecimento de que a prestação de assistência farmacêutica pelo Estado constitui materialização do direito constitucional à vida e à saúde, além de imposição legal; a assistência farmacêutica é entendida como um direito jurisdicionalmente tutelável do qual decorre o poder do cidadão de exigir, do estado, a prestação; (2) dificuldade dos julgadores de lidarem com os conceitos técnicos envolvidos e a incapacidade ou desinteresse dos réus em explicá-los, o que confere baixíssimo ou ausente conteúdo técnico às peças processuais; (3) preponderância da prescrição médica sobre quaisquer outros argumentos; (4) precedência de disposições constitucionais sobre preceitos legais que instituem determinados instrumentos de gestão da política; (5) ausência de preocupação dos julgadores com as consequências econômicas e distributivas das suas decisões e nãoconsideração do risco de comprometimento de outras ações programadas em decorrência de sentenças concessivas. Conclusões: a jurisprudência do TJDF sobre a matéria foi conformada pelo julgamento das ações por medicamentos antiretrovirais impetradas por pacientes de AIDS contra a SESDF no final da

(*) Médico, formado pela Universidade Federal do Rio Grande do Sul (UFRGS), especialista em Saúde Pública pela Universidade de São Paulo (USP); Consultor Legislativo do Senado Federal. E-mail: <romero@senado.gov.br>. Recebido em 19.05.09. Aprovado em 08.09.09. 
década de 90 e se consolidou no período estudado, favorecendo a efetivação do acesso ao medicamento, ainda que com impactos relevantes sobre aspectos técnicos, financeiros e de gestão da política de assistência farmacêutica adotada.

\section{Palavras-chave}

Assistência Farmacêutica; Direito à Saúde; Judicialização; Jurisprudência; Medicamentos.

\section{ABSTRACT}

Objective: To describe the conformation and characteristics of the jurisprudence of Distrito Federal Court of Justice (TJDF) (Brazil) related to medicines lawsuits. Method: Documental research in TJDF database on judgments of this court in the period of 2001 to 2005, referring lawsuits that pleaded medicaments supplying for Distrito Federal Secretariat of Health (SESDF). Results: The main characteristics of jurisprudence consolidated in TJDF on the subject are: (1) recognition that the State rendering of pharmaceutical care constitutes materialization of constitutional right to life and health and legal imposition; pharmaceutical care is understood as a jurisdictionally tutorable right from which elapses the power of citizen to demand, of the State, to render it; (2) the difficulty of the judges in dealing with involved technical concepts and the incapacity or disinterest of defendants in explaining the result in little or absent technical content of the procedural briefs; (3) the preponderance of medical prescription over any other arguments; (4) the noconsideration of legal provisions in face of the precedence of constitutional provisions that institute the subjective public right to health; (5) the absence of concern by judges with economic and distributive consequences of their decisions; the reiterated manifestation that budgetary limitations cannot supplant constitutional provisions; decisions not to consider, also, the risk of compromising other programmed actions as result of concessive sentences. Conclusions: The judgment of lawsuits on antiretrovirais medicines, petitioned for AIDS patients against the SESDF, in the late ' 90 , shaped the TJDF jurisprudence on the matter, that was consolidated in the studied period, promoting the materialization of the access to medicament as an element of the constitutional right to health, despite the negative impacts on technical, financial and managerial aspects of the adopted politic of pharmaceutical care.

\section{Keywords} to Health.

Drugs; Jurisprudence; Medicines Lawsuits; Pharmaceutical Care; Right 


\section{INTRODUÇÃO}

Os últimos anos da década de 90 constituíram um divisor de águas na Política de Medicamentos adotada no País e no campo da assistência farmacêutica pública que, apesar da restrição orçamentária pela qual passou o setor saúde, tiveram ampliados, substancialmente, os recursos à disposição de seu financiamento, o que permitiu sua diversificação, aumento de cobertura e avanço no processo de descentralização, tendências essas que se consolidaram nos anos seguintes.

A implantação da nova política e a ampliação de seu financiamento não foram, no entanto, suficientes para a ampliação do acesso ao medicamento na medida da demanda. Em decorrência, no início da década atual, observou-se o crescimento de um fenômeno que, se não era novo, ao menos, não tinha a intensidade que tomou: a judicialização da política de assistência farmacêutica, caracterizada por uma onda de decisões judiciais determinando a dispensação de medicamentos pelo Poder Público, com uma intensidade jamais vista.

Um estudo da sua ocorrência no Estado do Rio de Janeiro no período de 1991 a 2002 evidenciou a existência de mandados judiciais impetrados contra o estado e os municípios com vistas à obtenção de assistência farmacêutica em todos os anos estudados. No entanto, a partir de 1999, o crescimento do número desses mandados tornou-se exponencial. A maior parte dessas ações tinha como autores usuários do Sistema Único de Saúde (SUS) e referia-se a medicamentos de uso contínuo e de atenção básica. $O$ estudo concluiu, entre outras coisas, que municípios e o estado não cumpriam integralmente suas responsabilidades quanto à assistência farmacêutica, e que a excessiva judicialização decorrente gerava desgastes nas relações entre os Poderes Executivo e Judiciário e desvio de recursos da execução de ações programadas, no âmbito da atenção coletiva. ${ }^{(1)}$

Em 2003, o Conselho Nacional de Secretários de Saúde (CONASS) informava, em publicação própria, que "o significativo número de mandados judiciais que demandam o fornecimento de medicamentos de dispensação em caráter excepcional tem sido motivo de preocupação constante dos secretários estaduais de saúde". São dessa época, também, as primeiras tentativas para equacionar o problema, por meio da aproximação entre gestores do SUS e juízes. Na época, o CONASS oficiou a todos os presidentes de tribunais de justiça e procuradores-gerais de justiça dos Estados sobre

(1) MESSEDER, Ana Márcia; OSORIO-DE-CASTRO, Claudia Garcia Serpa; LUIZA, Vera Lucia. Mandados judiciais como ferramenta para garantia do acesso a medicamentos: a experiência do Estado do Rio de Janeiro, Brasil. Cadernos de Saúde Pública, Rio de Janeiro, v. 21, n. 2, p. 525-534, mar./abr. 2005. 
a utilização de protocolos clínicos e diretrizes terapêuticas para orientar a decisão judicial quando das demandas judiciais por medicamentos de dispensação em caráter excepcional. ${ }^{(2)}$

Entre 2002 e 2003, os recursos gastos pelos Estados e o Distrito Federal com medicamentos de dispensação em caráter excepcional triplicaram, alcançando a soma de um bilhão de reais, em 2003. Um seminário convocado para tratar da questão reconheceu "a desorganização que as ações judiciais causam no sistema". ${ }^{(3)}$ Em abril de 2004, novamente, o CONASS manifestava que "demandas judiciais por medicamentos excepcionais (...) representam, atualmente, uma das questões mais preocupantes para os gestores estaduais". (4)

Em outubro de 2004, o Tribunal de Contas da União, em auditoria realizada em várias unidades federadas, entre junho e setembro de 2004, com o objetivo de avaliar o desempenho da Ação Assistência Farmacêutica para Aquisição e Distribuição de Medicamentos de Dispensação em Caráter Excepcional, reconheceu que "Estados e o Ministério da Saúde têm enfrentado um crescente número de demandas judiciais para o fornecimento de medicamentos excepcionais, especialmente no biênio 2003-2004", e que esse tem sido um dos principais problemas da área, podendo mesmo vir a inviabilizá-la, caso se mantenha o formato atual e não se reverta a situação. ${ }^{(5)}$

Um estudo do fenômeno no Município de São Paulo, no ano de 2005, mostrou que, naquele ano, foram impetradas 107 ações contra o poder público municipal, que resultaram em um gasto extra de 876 mil reais. É interessante verificar que a grande maioria dos medicamentos demandados era de atenção básica (para diabetes, câncer, hipertensão, osteoporose) e se encontravam nas listagens adotadas pela secretaria municipal de saúde. Em mais de $70 \%$ dos casos, os pacientes demandantes tinham sido atendidos em um serviço do SUS - próprio, na maior parte - onde não receberam os medicamentos de que necessitavam. ${ }^{(6)}$

Atualmente, os governos federal, estaduais e municipais, gestores do SUS sofrem uma avalanche de ordens judiciais determinando a dispensação de medicamentos, o que gera efeitos negativos, especialmente sobre o gerenciamento da assistência farmacêutica nos estados e sobre os seus

(2) CONSELHO NACIONAL DE SECRETÁRIOS DE SAÚDE. Para entender a Gestão do Programa de Medicamentos de Dispensação em Caráter Excepcional. Brasília, 2004. (Série CONASS Documenta, n. 3).

(3) CONSELHO NACIONAL DE SECRETÁRIOS DE SAÚDE. Carta de Porto Alegre. Relatório do Seminário 'O SUS, o Judiciário e o Acesso aos Medicamentos Excepcionais' (Porto Alegre, 9-10 de julho de 2004). In: CONASS. Nota Técnica 13/2005. Brasília, jul. 2005.

(4) CONSELHO NACIONAL DE SECRETÁRIOS DE SAÚDE (a). Para entender a Gestão do Programa de Medicamentos de Dispensação em Caráter Excepcional, cit.

(5) TRIBUNAL DE CONTAS DA UNIÃO. Avaliação do TCU sobre a Ação Assistência Financeira para Aquisição e Distribuição de Medicamentos Excepcionais. Brasília: TCU, 2005. (Sumários Executivos, 23). (Também disponível em: <www.tcu.gov.br/avaliacaodeprogramasdegoverno>).

(6) VIEIRA, Fabiola Sulpino; ZUCCHI, Paola. Distorções causadas pelas ações judiciais à política de medicamentos no Brasil. Revista de Saúde Pública, São Paulo, v. 41, n. 2, p. 212-222, 2007. 
benefícios diretos, como a interrupção do tratamento de pacientes regulares em razão da transferência de medicamentos em estoque que Ihes seriam destinados para pacientes beneficiados por determinação judicial|(7). Essas decisões da Justiça comprometem, assim, a dispensação regular, o atendimento de prioridades definidas e a implementação das políticas de assistência farmacêutica aprovadas, já que os gestores precisam remanejar recursos vultosos para atender situações individuais.

As explicações para a judicialização da política pública de assistência farmacêutica dos últimos anos não estão suficientemente esclarecidas, mas, certamente, dois fatores estão associados na sua produção: a insuficiência da assistência farmacêutica prestada tanto no âmbito do SUS como no dos planos privados de assistência à saúde e o crescimento do reconhecimento do direito à saúde e, no seu âmbito, ao acesso ao medicamento, por parte de segmentos cada vez maiores da nossa população.

A insuficiência de cobertura a medicamentos nos dois sistemas - o público e o privado - é demonstrada por estudos recentes de gastos familiares com saúde que mostram que as despesas com medicamentos são, em volume, os mais importantes dispêndios com saúde das famílias brasileiras, superando, inclusive, os gastos diretos com mensalidades de planos de saúde e pagamento por consultas, exames, internações, órteses e próteses. ${ }^{(8)(9)(10)}$ Entre os segmentos populacionais de menor renda, 0 comprometimento proporcional da renda familiar com a compra direta de medicamentos é ainda maior.(11) Corroborando essa afirmação, a área de assistência farmacêutica do Ministério da Saúde informava, às vésperas da $1^{\text {a }}$ Conferência Nacional de Medicamentos e Assistência Farmacêutica de 2005, que $80 \%$ dos medicamentos dispensados no País assim eram por uma farmácia comercial sob a forma de compra direta pelo paciente-consumidor. ${ }^{(12)}$

Como os planos de saúde estão isentados, por lei, de dar cobertura a medicamentos para tratamentos domiciliares e ambulatoriais, a necessidade de rever essa regulamentação tem sido objeto de recomendações reiteradas e não implementadas pelo Legislativo federal, entre as quais se destaca o relatório da comissão parlamentar de inquérito realizada pela Câmara dos Deputados em 2003. ${ }^{(13)}$

(7) TRIBUNAL DE CONTAS DA UNIÃO, cit.

(8) ORGANIZAÇÃO MUNDIAL DA SAÚDE (OMS). The World Health Report, 2006. Genebra, 2006. [referente a informações de 2003].

(9) INSTITUTO BRASILEIRO DE GEOGRAFIA E ESTATÍSTICA. Pesquisa de Orçamento Familiar. Rio de Janeiro, 2003.

(10) FUNDAÇÃO OSWALDO CRUZ (FIOCRUZ). Pesquisa Mundial de Saúde: Brasil 2003. Rio de Janeiro, 2004.

(11) INSTITUTO BRASILEIRO DE GEOGRAFIA E ESTATÍSTICA, cit.

(12) MINISTÉRIO DA SAÚDE. Conselho Nacional de Saúde. Relatório Final da $1^{\text {a }}$ Conferência Nacional de Medicamentos e Assistência Farmacêutica. Brasília, 2005.

(13) CÂMARA DOS DEPUTADOS. Comissão Parlamentar de Inquérito com a finalidade de investigar denúncias de irregularidades na prestação de serviços por empresas e instituições privadas de planos de saúde. Relatório final. Brasília, nov. 2003. 
Sem acesso aos medicamentos de que necessitam, resta aos pacientes — os do SUS e os dos planos - a via judicial.

Por outro lado, a situação de ascensão institucional do Poder Judiciário na proteção dos direitos individuais e coletivos e no controle de políticas públicas e da atuação dos poderes constituídos é um fenômeno descrito em diversas sociedades contemporâneas, como decorrente do aprofundamento do processo democrático e de redefinição da relação entre os três poderes. ${ }^{(14)(15)(16)}$

Ele é entendido como decorrência natural do surgimento do chamado Estado Social - "que incorporou promessas e compromissos de vulto nas cartas constitucionais" - o que aumentou a pressão e, no seu bojo, a demanda judicial pela concretização dos novos direitos de cidadania constitucionalizados. ${ }^{(17)}$

Em nosso País, os estudiosos da matéria(18)(19)(20) registram, da mesma forma que em outros países, a elevação considerável da demanda da sociedade por justiça, a partir da promulgação da Constituição de 1988. Eles identificam, no entanto, que, no Brasil, além da reconquista das liberdades democráticas e da cidadania, da ampliação do catálogo de direitos e garantias fundamentais e da correspondente conscientização das pessoas e dos grupos sociais sobre seus direitos, outro elemento contribuiu decisivamente para a judicialização de políticas públicas: a introdução de novos e efetivos instrumentos processuais para garantir sua efetividade e a tutela daqueles direitos.

Dessa forma, no Brasil pós-1988, além da evolução do direito de acesso à justiça, ocorreu a instituição de mecanismos assecuratórios do acesso a direitos constitucionais, de alguma forma, preteridos. (21) $\mathrm{Na}$ opinião de Casagrande, a Constituição de 1988 promoveu não apenas a criação de um amplo sistema de garantias de direitos, como uma série de inovações processuais a seu serviço, somadas à inédita posição de independência do Judiciário em relação aos demais poderes. ${ }^{(22)}$ Entre esses mecanismos, ressalta o alargamento de funções e do âmbito de atuação do Ministério Público.

(14) TATE, Neal; VALLINDER, Torbjörn (Orgs.). The global expansion of Judicial Power. New York: New York University Press, 1995.

(15) NUNES JÚNIOR, Amandino Teixeira. Considerações sobre a Judicialização da Política no Brasil. Cadernos Aslegis (Brasília), v. 8, n. 29, p. 33-39, maio/dez. 2006.

(16) YEPES, Rodrigo Uprimny. A judicialização da política na Colômbia: casos, potencialidades e risco. Sur Revista Internacional de Direitos Humanos (São Paulo), a. 4, n. 6, p. 53-70, 2007.

(17) SOUZA JÚNIOR, Antônio Humberto. O Supremo Tribunal Federal e as questões políticas. Porto Alegre: Síntese, 2004.

(18) CASAGRANDE, Cássio. Ministério Público, ação civil pública e a judicialização da política perspectivas para o seu estudo. Boletim Científico da Escola Superior do Ministério Público da União, Brasília, a. 1, n. 3, p. 21-34, abr./jun. 2002.

(19) SOUZA JÚNIOR, Antônio Humberto. op. cit.

(20) NUNES JÚNIOR, Amandino Teixeira. op. cit.

(21) SOUZA JÚNIOR, Antônio Humberto. op. cit.

(22) CASAGRANDE, Cássio. op. cit. 
No campo do direito à saúde, o texto constitucional de 1988 trouxe considerável inovação ao definir as ações e serviços de saúde como de relevância pública e determinando, assim, a essencialidade de sua prestação para o interesse social. ${ }^{(23)}$ A construção do Sistema Único de Saúde como mecanismo para assegurar o acesso universal àquelas ações e serviços e à atenção integral, no entanto, não alcançou todos os aspectos da atenção à saúde: a assistência farmacêutica, ainda que tivesse seu financiamento e cobertura ampliados, permaneceu como um dos aspectos menos institucionalizados e menos universalizados. A insuficiência da assistência farmacêutica prestada tanto pelo SUS como pelos planos de saúde foi, assim, um dos motivos pelos quais as pessoas, as associações de doentes e o próprio Ministério Público optassem pela via judicial para obter acesso ao medicamento como parte do direito constitucional à saúde.

\section{MATERIAL E MÉTODO}

O estudo teve, por objetivo, analisar como se conformou e que características tomou a jurisprudência do Tribunal de Justiça do Distrito Federal (TJDF) em relação a ações de medicamentos, isto é, referente a ações que pleiteavam o fornecimento de medicamentos pela Secretaria de Saúde do Distrito Federal (SESDF), como mecanismo assecuratório do direito constitucional à saúde.

É uma pesquisa documental na qual foram estudados os acórdãos julgados pelo TJDF nos anos de 2001 a 2005, tratando de acesso a medicamentos, correspondentes a ações iniciadas nos anos de 1997 a 2005.

Foram identificados e analisados 221 acórdãos julgados no período considerado, a partir da base de dados mantida pelo TJDF, com acesso por meio da internet.

\section{RESULTADOS}

\section{Ações, autores, réus e medicamentos pleiteados}

A análise dos teores desses acórdãos permite verificar a existência de um padrão mutável, durante o período analisado, das características do demandante de proteção jurídica, do medicamento demandado e das ações

(23) DELDUQUE, Maria Célia; OLIVEIRA, Mariana Siqueira de Carvalho. O papel do Ministério Público no campo do Direito e Saúde. In: MINISTÉRIO DA SAÚDE. Fundação Oswaldo Cruz. Questões de direito sanitário. Brasília: Ed. do Ministério da Saúde, 2006. 
impetradas, bem como a evolução dos argumentos apresentados por autores e réus, que foram conformando a jurisprudência daquela corte sobre a matéria. Um padrão, no entanto, permaneceu imutável: o provimento, naquela instância, de todas as ações a favor do autor-paciente - inclusive com antecipação de tutela e concessão de segurança - e o não-provimento dos apelos, recursos e agravos do réu pela reforma das sentenças.

Segundo os registros da Assessoria Jurídica e Legislativa da SESDF, o número de ações de medicamentos impetradas contra a Secretaria tem sido crescente: 281, em 2003; 378, em 2004; 604, em 2005; e 682, em 2007(24). Um número significativo delas chegou à deliberação do Pleno do TJDF, originando os acórdãos que foram objeto de análise.

Em relação à natureza da ação, predominaram as ações cominatórias, que perfazem $57 \%$ do total. Esse padrão, no entanto, não é constante no tempo: nos anos iniciais do período estudado, a maior parte das ações são cautelares e ordinárias, passando a prevalecer as ações cominatórias - em especial, os mandados de segurança - nos anos finais do período. (Tabela 1.)

Tabela 1 - Ações de medicamentos em acórdãos julgadas pelo TJDF, segundo o ano e a natureza da inicial. Distrito Federal, 1997 a 2005.

\begin{tabular}{|l|c|c|c|c|c|c|c|c|c|c|}
\hline Ação \ano da inicial & 1997 & 1998 & 1999 & 2000 & 2001 & 2002 & 2003 & 2004 & 2005 & \\
\hline Cautelar & 2 & 4 & 3 & - & 2 & - & - & - & - & 11 \\
\hline Ordinária & - & 3 & 7 & 7 & 2 & 7 & 3 & - & - & 29 \\
\hline Cominatória & - & - & 3 & 1 & 2 & 32 & 9 & 45 & 34 & 126 \\
\hline De conhecimento & - & - & - & 2 & 2 & 4 & 1 & 3 & - & 12 \\
\hline Civil pública & - & - & - & 2 & - & 2 & 2 & 2 & - & 8 \\
\hline Outras & - & - & 1 & - & - & - & 1 & - & - & 2 \\
\hline Sem informação & - & - & 5 & 1 & 2 & 8 & 4 & 9 & 4 & 33 \\
\hline Total & 2 & 7 & 19 & 13 & 10 & 53 & 20 & 59 & 38 & 221 \\
\hline
\end{tabular}

Fonte: Acórdãos TJDF. Elaborado pelo autor.

Os autores são, majoritariamente, particulares (Tabela 2). Infelizmente, em $80 \%$ dos casos não foi possível identificar o condutor da ação.

(24) Levantamento realizado pelo autor nos bancos de dados da Assessoria. 
Tabela 2 - Ações de medicamentos em acórdãos julgadas pelo TJDF, segundo o autor. Distrito Federal, 1997-2005.

\begin{tabular}{|l|c|c|}
\hline \multicolumn{1}{|c|}{ Autor } & Número & $\%$ \\
\hline Particular & 210 & 95,0 \\
\hline Associação de pacientes & 5 & 2,3 \\
\hline Ministério Público & 5 & 2,3 \\
\hline Sem informação & 1 & 0,4 \\
\hline Total & 221 & 100,0 \\
\hline
\end{tabular}

Fonte: Acórdãos TJDF. Elaborado pelo autor.

A grande preponderância de autores individuais representados por advogados particulares foi também encontrada por Marques e Dallari( ${ }^{25)}$ e por Vieira e Zucchi, em São Paulo(26). Messeder, Castro e Luiza, no entanto, encontraram, no Estado do Rio de Janeiro, entre 1991 e 2002, uma proporção elevada e crescente de ações conduzidas pela defensoria pública ${ }^{(27)}$, uma tendência que também observamos no Distrito Federal, nos anos finais do período estudado.

Esse é um dado importante para analisar a abrangência e equidade do acesso a medicamentos por meio de ações judiciais. Se a grande maioria das ações é proposta por particulares, por meio de advogados, isso pressupõe que os autores têm condições socioeconômicas suficientemente elevadas para custear uma causa (além de conexões sociais, grau de escolaridade e discernimento suficientes para conhecer a possibilidade de recurso judicial e decidir-se pelo seu uso). Existe um custo fixo inicial para causas jurídicas com advogados particulares que não é acessível aos mais pobres. Daí se poderia pensar em um cenário de indivíduos de renda mais elevada, demandando medicamentos de alto custo (que justifiquem o pagamento de honorários advocatícios). Por outro lado, se houvesse prevalência de ações conduzidas pela defensoria pública, isso indicaria a busca de atendimento de direito difuso, em um quadro de não atendimento da população de baixa renda em seu direito de receber medicação constante nas relações de medicamentos do SUS, e que deveriam constar dos estoques da Secretaria de Saúde. Infelizmente, a imprecisão dos dados, impedindo identificar o condutor da ação na maior parte dos casos, não permite avançar nesse aspecto da análise.

(25) MARQUES, Silvia Badim; DALLARI, Sueli Gandolfi. Garantia do direito social à assistência farmacêutica no Estado de São Paulo. Revista de Saúde Pública, São Paulo, v. 41, n. 1, p. 101-107, 2007.

(26) VIEIRA, Fabiola Sulpino; ZUCCHI, Paola. op. cit.

(27) MESSEDER, Ana Márcia; OSORIO-DE-CASTRO, Claudia Garcia Serpa; LUIZA, Vera Lucia. op. cit. 
No polo passivo das ações, estão, preponderantemente, serviços públicos de saúde do Distrito Federal. Em mais de $90 \%$ das ações, o réu é o Governo do Distrito Federal ou o Secretário de Saúde do Distrito Federal. Um número muito pequeno de ações foi impetrado contra operadoras de planos privados de saúde. (Tabela 3.)

Tabela 3 - Ações de medicamentos em acórdãos julgados pelo TJDF, segundo o réu. Distrito Federal, $1997-2005$.

\begin{tabular}{|l|r|r|}
\hline \multicolumn{1}{|c|}{ Réu } & N. & $\%$ \\
\hline Distrito Federal & 156 & 70,7 \\
\hline Secretário de Saúde & 52 & 23,6 \\
\hline Fundação Hospitalar do Distrito Federal & 2 & 0,9 \\
\hline Diretor de Procedimentos de Alta Complexidade da SES & 1 & 0,4 \\
\hline Chefe da Farmácia Central da SES & 1 & 0,4 \\
\hline Diretor de Medicamento da SES & 1 & 0,4 \\
\hline Diretor do Hospital de Base & 1 & 0,4 \\
\hline Diretor do Hospital Universitário & 1 & 0,4 \\
\hline Operadoras de plano de saúde & 6 & 2,8 \\
\hline Total & 221 & 100,0 \\
\hline
\end{tabular}

Fonte: Acórdãos TJDF. Elaborado pelo autor.

A identificação do réu como "o Distrito Federal" é mais frequente nos anos iniciais da série estudada e como "o Secretário de Saúde", nos anos posteriores. Outras autoridades ligadas à SESDF (diretores das áreas de assistência farmacêutica e de procedimentos de alta complexidade, em especial) aparecem raramente no polo passivo das ações. Marques e Dallari encontraram padrão similar nas ações de fornecimento de medicamentos do Estado de São Paulo, entre 1997 e 2004. ${ }^{(28)}$

O argumento de que o Distrito Federal, por meio de seu governo ou da Secretaria de Saúde, não constituía polo passivo legítimo da ação foi precoce e insistentemente apresentado pelos réus e sistematicamente recusado pelos julgadores. Apesar disso, em todo o período estudado, o GDF e a Secretaria de Saúde persistiram em trazer, reiteradamente, em suas defesas, recursos e agravos, o argumento de que a competência da prestação é do Ministério da Saúde e não sua, e na necessidade de denunciação da União à lide.

$\mathrm{O}$ argumento foi rebatido também de forma reiterada com base, sempre, nos mesmos elementos: de que o art. 198 da Constituição Federal instituiu

(28) MARQUES, Silvia Badim; DALLARI, Sueli Gandolfi. op. cit. 
um sistema de saúde descentralizado, com direção única em cada esfera de governo, e a determinação expressa da Lei Orgânica do DF de que é da competência do GDF prestar "assistência social aos necessitados". Voto, proferido em 2004, sintetiza a posição do TJDF que consolidou jurisprudência a respeito:

Pelo mesmo fundamento, [é] indiscutível a legitimidade passiva do Distrito Federal, pois, conforme já ressaltado, na manutenção dos serviços públicos de saúde, preserva tal ente razoável parcela de sua autonomia administrativa, a qual deverá ser utilizada com o fim de atender as necessidades surgidas no âmbito do respectivo território. (Processo n. 2002.01.1.052 740-5, acórdão 191.073, julgado em 22.03.04).

Em $60 \%$ das ações, é possível identificar o serviço em que o autor estava sendo atendido e que Ihe prescreveu o medicamento pleiteado, evidenciando-se que $79 \%$ dos pleiteantes eram pacientes de um serviço mantido pelo Estado ${ }^{(29)}$, a grande maioria dos quais $(67 \%)$ estava sendo atendida em unidades da rede mantida pelo Governo do Distrito Federal. Chama a atenção, a proporção significativa de pacientes cuja assistência médica estava sendo feita por clínicas privadas ou por médicos particulares ( $21 \%$ dos autores em relação aos quais se conhece o serviço que os atendia), mas que, ainda assim, pleiteiam que a assistência farmacêutica seja prestada pela SESDF.

Resultados similares foram observados por Messeder, Castro e Luiza, no Estado do Rio de Janeiro, na década de $90^{(30)}$, e por Vieira e Zucchi, no Município de São Paulo, em 2005(31).

A demanda por proteção jurídica disse respeito a variados tipos de patologias, cujas necessidades de assistência farmacêutica as originaram. Observamos que o tipo de patologia envolvida variou com o tempo e, por essa razão, também o grupo terapêutico dos medicamentos pleiteados. (Tabela 4.)

(29) Os serviços públicos de saúde do Distrito Federal não estão organizados na forma de um sistema único, conforme determina a Constituição Federal. Além da rede mantida pela SESDF, existe um número significativo de serviços ambulatoriais e hospitalares mantidos pelo Estado (ministérios - entre os quais o hospital universitário, gerido pelo Ministério da Educação - Fundação das Pioneiras Sociais, as três forças armadas e a polícia militar) que não se articulam entre si, não se organizam em rede, competem por recursos e não se submetem à direção única. Dessa forma, não é possível falar em SUS-DF.

(30) MESSEDER, Ana Márcia; OSORIO-DE-CASTRO, Claudia Garcia Serpa; LUIZA, Vera Lucia. op. cit.

(31) VIEIRA, Fabiola Sulpino; ZUCCHI, Paola. op. cit. 
Tabela 4 - Ações de medicamentos em acórdãos julgadas pelo TJDF, segundo $o$ ano da inicial e o tipo de doença de que o impetrante era portador. Distrito Federal, 1997 a 2005.

\begin{tabular}{|l|c|c|c|c|c|c|c|c|c|c|}
\hline Doença I ano & 1997 & 1998 & 1999 & 2000 & 2001 & 2002 & 2003 & 2004 & 2005 & \\
\hline AIDS & 2 & 7 & 18 & 11 & 7 & 2 & 1 & 4 & 1 & 53 \\
\hline Dist. crescimento & - & - & 1 & - & - & - & 1 & 2 & - & 4 \\
\hline S. de Gaucher & - & - & - & 2 & - & - & - & 1 & - & 3 \\
\hline Esclerose múltipla & - & - & - & - & 1 & 12 & - & - & - & 13 \\
\hline Transt. mentais & - & - & - & - & 1 & 1 & 2 & 4 & 5 & 13 \\
\hline Cânceres & & - & - & - & 1 & 17 & 5 & 6 & 7 & 36 \\
\hline Fibrose cística & - & - & - & - & - & 1 & - & - & - & 1 \\
\hline ELA* & - & - & - & - & - & 2 & - & 1 & - & 3 \\
\hline Das neurológicas & - & - & - & - & - & 2 & 2 & 5 & 2 & 11 \\
\hline Hepatite C & - & - & - & - & - & 11 & 4 & 3 & 2 & 20 \\
\hline Diabete mellitus & - & - & - & - & - & 1 & - & 2 & - & 3 \\
\hline S. de Byler & - & - & - & - & - & - & 1 & - & - & 1 \\
\hline Artropatias & - & - & - & - & - & - & - & 5 & 13 & 18 \\
\hline Osteoporose & - & - & - & - & - & - & - & 10 & - & 10 \\
\hline Da de Alzheimer & - & - & - & - & - & - & - & 2 & 1 & 3 \\
\hline Da de Fabry & - & - & - & - & - & - & - & 2 & - & 2 \\
\hline S. de Sjögren & - & - & - & - & - & - & - & 1 & - & 1 \\
\hline Outras & - & - & - & - & - & 2 & 2 & 7 & 4 & 15 \\
\hline Sem informação & - & - & - & - & - & 2 & 2 & 4 & 3 & 11 \\
\hline Total & 2 & 7 & 19 & 13 & 10 & 53 & 20 & 59 & 38 & 221 \\
\hline
\end{tabular}

Fonte: Acórdãos TJDF. Elaborado pelo autor. ${ }^{\star} E L A=$ esclerose lateral amiotrófica

Em 94,5\% dos acórdãos estudados foi possível identificar o medicamento pleiteado. Desse total de medicamentos identificados, $58,5 \%$ eram identificados pelo nome genérico ou denominação comum brasileira, $40,1 \%$, pelo nome de marca e o restante $(1,4 \%)$ pelo grupo terapêutico, permitindo verificar que, ainda que $62,1 \%$ das ações dissessem respeito a apenas quatro grupos terapêuticos, elas abrangem uma grande variedade deles.

Outro aspecto relevante é que, em $47,6 \%$ das ações, os medicamentos pleiteados faziam parte da Relação Nacional de Medicamentos Essenciais (RENAME), versão de $2002^{(32)}$.

(32) MINISTÉRIO DA SAÚDE. Relação Nacional de Medicamentos Essenciais (RENAME). 3. ed. Brasília, 2002. (Série B. Textos Básicos de Saúde.) 
Do ponto de vista da cronologia, é possível, assim, observar, até 2001, um número pequeno de ações e, na sua quase totalidade, impetrada por doentes de AIDS requerendo o fornecimento de antiretrovirais. A partir de então, aumentou o número de ações solicitando o fornecimento daqueles e de outros antiretrovirais inovadores ou, como a eles se referem os acórdãos, "medicamentos de vanguarda", antes mesmo de eles terem entrado no mercado nacional, terem sido registrados no Ministério da Saúde ou selecionados para os protocolos clínico-terapêuticos vigentes. Muitas ações dessa época - por sinal, sempre concedidas - pediam "todos os medicamentos necessários ao tratamento" ou "e outros que vierem a ser prescritos", além da realização de exames de resistência fenotípica do HIV.

Foram essas ações que estabeleceram as bases da jurisprudência do TJDF sobre a matéria.

A partir de 2002, o número de ações sofreu um incremento significativo, ao mesmo tempo em que os pacientes com AIDS deixaram de ser os principais autores das ações que passaram a incluir pacientes com cânceres (16,3\% das ações), hepatite C $(9,0 \%)$, artropatias $(8,1 \%)$, esclerose múltipla $(5,9 \%)$, transtornos mentais $(5,9 \%)$, doenças neurológicas $(5,0 \%)$ e osteoporose $(4,5 \%)$, entre outros, verificando-se, assim, que o espectro de doenças e pacientes que requerem proteção jurisdicional cresceu muito a partir de então. Portadores de doenças raras, em ações pessoais ou impetradas por associações de doentes, pleitearam o fornecimento de medicamentos - em geral, experimentais ou fora do mercado brasileiro e de elevado custo - a partir de 2000, mas, principalmente, durante os anos de 2003 e 2004. Eles representam, no entanto, menos de 5\% do total de ações do período.

Essa informação contraria a opinião corrente de que as ações judiciais demandando fornecimento de medicamentos são impetradas, majoritariamente, por portadores de doenças raras e envolvem medicamentos de dispensação em caráter excepcional. Na verdade, em metade das ações estudadas, os medicamentos pleiteados faziam parte da Rename.

Esse padrão - AIDS como condição patológica dominante nas ações até os primeiros anos da década; grande diversificação dessas condições e dos grupos terapêuticos dos medicamentos pleiteados, a partir de então; e maioria de ações voltadas para medicamentos para o tratamento de condições de atenção básica e de média complexidade - também é registrado no Rio de Janeiro ${ }^{(33)}$ e em São Paulo(34).

(33) MESSEDER, Ana Márcia; OSORIO-DE-CASTRO, Claudia Garcia Serpa; LUIZA, Vera Lucia. op. cit. (34) VIEIRA, Fabiola Sulpino; ZUCCHI, Paola. op. cit. 


\section{Conformação da jurisprudência}

\subsection{Os argumentos dos autores}

Dois argumentos estão presentes nos arrazoados de todos os autores que ingressaram com ações no TJDF pleiteando assistência farmacêutica no período estudado: o entendimento de que a prestação dessa assistência por parte do Estado constitui um direito constitucional e legal que Ihes está sendo tolhido e o fato de não disporem de recursos financeiros para adquirir, por contra própria, os medicamentos pleiteados. Nesse último caso, o alto custo dos medicamentos ou sua necessidade por tempo prolongado é, com frequência, um argumento acrescido.

A partir de 2002, passam a constar dos autos de forma cada vez mais frequente os registros, feitos tanto pelos autores-pacientes como pelos próprios julgadores, de denúncias de descontinuidade e omissão da prestação do serviço pela SESDF e da "via crucis pela qual está passando a população que não tem recursos para adquirir medicamentos" (Processo n. 2002.00.2.002 247-6, acórdão 164.261, julgado em 20.08.02.)

Constatações do fato aparecem nos votos e decisões, e são eloquentes:

Impende destacar, ainda, que o Ministério Público do Distrito Federal vem identificando falhas na distribuição de medicamentos por parte da Secretaria de Saúde do Distrito Federal desde novembro de 2001, o que deu origem à Recomendação n. 001/2002, da Promotoria de Justiça de Defesa da Saúde, bem assim à propositura das Ações Civis Públicas n. 2002011075801-5 e 2003011028275-2. (Processo $n$. 2004.00.2.006 677-8, acórdão 215.115, julgado em 19.04.05.)

É uma situação insustentável, é uma violência. E essa alegação de que não tem verba é inaceitável, porque sobra dinheiro para obras que podem interessar a uma minoria da população, àquela minoria que dirige automóveis, que têm automóveis. Então se constroem viadutos e mais viadutos, pontes e mais pontes, mas faltar dinheiro? (...) 0 problema de gestão é patente, porque como se deixam os depósitos, as farmácias dos hospitais vazios de remédios que são procurados naturalmente pela população, pelos doentes graves? Tem de haver uma reserva. Não falta só remédio para leucemia, não; faltam antibióticos, faltam remédios para problemas cardíacos, para pressão alta. Então, se o Tribunal de Justiça do Distrito Federal tomar, a partir de agora, uma posição firme no sentido de acolher esses pedidos, acho que estaremos fazendo justiça, estaremos dizendo: 'estamos aqui', e estaremos fazendo um benefício a essas populações mais carentes. Cumprindo nosso dever de distribuir justiça. (Processo n. 2002.00.2.002 247-6, acórdão 164.261, julgado em 20.08.02.) 
(...) a lamentável omissão da Administração em cumprir e fazer cumprir os mais elementares direitos garantidos na Constituição Federal, diante da qual impõe-se seja esta compelida, via ação judicial, a fazê-lo. (Processo n. 2002.01.1.095 444-5, acórdão 182.917, julgado em 01.09.03.)

É inadmissível a demonstração de indiferença do Estado à solução dos problemas submetidos à sua apreciação. (Processo n. 2003.00.2.005 6553, acórdão 180.905, julgado em 14.10.03.)

Diante das reiteradas negativas do Poder Público de prestar assistência às pessoas que não dispõem de recursos para custear tratamento médico-hospitalar, o Judiciário tem se mostrado sensível à demanda de pleitos como o que ora se apresenta, e a jurisprudência tem se firmado no sentido de impor ao Estado o cumprimento de tal mister. (Processo n. 2002.01.1.052 025-9, acórdão 188.299, julgado em 05.02.04.)

Em decorrência, a insuficiência da assistência farmacêutica prestada na rede pública, a descontinuidade da prestação do serviço, e mesmo sua omissão, passaram a figurar com elevada frequência entre as razões pelas quais os impetrantes recorrem à Justiça.

A partir da edição, pela SESDF, da Portaria n. 14, de 2001, que regulamentou a dispensação de medicamentos em caráter excepcional, obrigando ao cadastramento do paciente e ao seu acompanhamento e a prescrição por profissional da rede da SESDF, a carência de serviços especializados e a insuficiência da assistência médica oferecida criaram problemas adicionais para os pacientes usuários daquela classe de medicamentos, aumentando a demanda por ações judiciais e acrescentando, entre as razões dos autores, o que denominavam de "burocracia" ou "burocratização excessiva" que os estava impedindo de usufruir o que entendiam ser um direito líquido e certo.

Independentemente das notícias de falência do sistema de saúde do Distrito Federal, diariamente divulgadas pela mídia, o que se nota, no presente caso, é que, de fato, o impetrante não encontrou alternativa para obter os meios necessários à preservação de sua saúde, senão pela ordem expedida em cumprimento à liminar deferida em seu favor. Acresça-se que a douta autoridade coatora sequer prestou informações a respeito da sua omissão, limitando-se a noticiar a aquisição dos remédios prescritos ao impetrante. (Processo n. 2002.00.2.009 209-8, acórdão 185.791, julgado em 30.09.03.)

Lamentavelmente, a realidade que se nos espelha é a de que o atendimento pelo sistema público de saúde é lentíssimo, precário, tanto em recursos humanos quanto materiais, o que obriga muitos cidadãos que, aliás, pagam a contribuição compulsória respectiva, a buscarem o atendimento médico particular - não por opção, cumpre ressaltar, 
mas por necessidade - lembrando, inclusive, que nem todos os que assim agem detêm poder aquisitivo para tanto. Todavia, nos momentos cruciais, é comum tirar-se das verbas destinadas às despesas necessárias para não se ter que sujeitar às intempéries dos hospitais públicos. (...) Marcar uma consulta chega a ser tarefa tormentosa, pois, aqueles que o fazem nunca esperam menos de quatro meses para serem atendidos. Registre-se que até mesmo a própria marcação é procedimento revestido de acentuada burocracia e empecilhos, dado a falta de recursos humanos e materiais da rede pública hospitalar. Se o estado de saúde do paciente enseja intervenção médica imediata, ele finda, lamentavelmente, a perecer. (Processo n. 2004.00.2.002 3885, acórdão 202.130, julgado em 28.09.04.)

O que se observa é que, de modo geral, a saúde pública no Distrito Federal apresenta-se sucateada, diante da inércia da administração em prover os recursos necessários ao atendimento de sua população. Não se vislumbra uma intenção clara em resolver os problemas existentes. As autoridades competentes limitam-se a afirmar que o assunto está sendo enfrentado e que a solução demanda recursos financeiros, quando se tem notícia de que recursos da saúde são remanejados para propaganda institucional e aplicação em obras de infraestrutura. (Processo n. 2003.01.1.028 275-2, acórdão 203.001, julgado em 07.10.04.)

O número de processos individuais se avoluma, a demonstrar que a Administração do Distrito Federal, mesmo sabendo da suma gravidade das deficiências de sua rede de saúde, não tomou - e demonstra que não tomará - nenhuma providência eficiente para sanar os problemas. Parece suficiente alegar que estariam ocorrendo deficiências na estrutura burocrática, ou que não é possível o remanejamento de recursos, ainda que gravíssimos os casos apresentados para tratamento perante a rede de saúde do DF. Faz-se mister a concessão de medida que torne efetivo o direito à saúde, constitucionalmente protegido. O juiz só pode agir quando instado a fazê-lo. Assim, uma vez pleiteada sua atuação não pode se abster de entregá-la de forma útil e tempestiva a fim de proteger o bem da vida de qualquer lesão ou perecimento. (Processo n. 2002.01.1.117 197-4, acórdão 208.368, julgado em 06.12.04.)

A situação de desatendimento, de insuficiência de recursos materiais e humanos e de burocratização da atenção à saúde no DF, aparentemente, não foi alterada significativamente durante o período estudado, tomando por base o teor dos acórdãos do TJDF analisados. Em decisão, em 2005, o relator denuncia, mais uma vez:

Cabe ressaltar que é de conhecimento coletivo a falência do sistema público de saúde em nosso país. (...) No presente caso, como houve 
informação da existência de outro medicamento, sem dizer se pode ser usado pela impetrante, esta acabará por necessitar de nova consulta apenas para verificar a possibilidade de substituição da medicação, o que, como se ressaltou, é verdadeira via crucis, impedindo o acesso da impetrante ao medicamento de que necessita, podendo, inclusive, após a nova consulta, receber notícia negativa do médico para a possibilidade de substituição do remédio, protelando a recusa no fornecimento, que pode tornar-se infindável diante da burocracia estatal. (Processo n. 2005.00.2.002 838-4, acórdão 227.062, julgado em 30.08.05.)

Nos anos finais do período, uma nova alegação passa a compor conjunto de argumento dos autores que pleiteiam medicamentos inovadores ou de segunda linha: a falência terapêutica e a superveniência de reações adversas não-controláveis e sérias com os medicamentos de primeira linha ou selecionados.

Também de forma recorrente, pedem os autores, seja majorada a verba honorária, "porquanto não condizente com o trabalho desenvolvido pelo patrono da causa".

\subsection{Os argumentos dos réus}

Nos primeiros anos estudados, o GDF apresentou sempre, em suas defesas e recursos, duas alegações: a de que o fornecimento do medicamento pleiteado não era de sua competência, mas do Ministério da Saúde, e a de que a prestação não era cabida por se tratar o autor de pessoa não-residente no Distrito Federal.

Como esses argumentos foram sistematicamente considerados improcedentes, os réus passaram a arregimentá-los menos vezes e, no segundo caso, a substituí-lo por outros, entre os quais se destacam: a não inclusão do medicamento pleiteado nas relações de medicamentos e protocolos clínicos adotados pelo SUS; a inexistência do medicamento no mercado; a ausência, insuficiência ou indisponibilidade de recursos orçamentários ou financeiros, e o fato de o autor não ser cliente da SESDF.

A insuficiência de recursos e a necessidade de previsão orçamentária e financeira são alegações frequentes, em especial nos processos mais antigos. A seguinte formulação do argumento, em defesa do governo, demonstra o entendimento do que pretendia que prevalecesse:

É necessário lembrar que a atividade do Estado para fazer face ao cumprimento dos preceitos constitucionais deverá ser planejada; o GDF não pode ser condenado a fornecer a certos cidadãos, por tempo indeterminado, um número indeterminado de medicamentos, sem que 
se saiba quanto vão custar e se há recursos no orçamento para tal compra. (Processo n. 2000.01.1.025572-2, acórdão 140.533, julgado em 19.03.01.)

A ideia teve dificuldade de prosperar, apesar de encontrar reflexo em alguns votos isolados como, por exemplo:

A Constituição assegura [o direito à saúde, à assistência farmacêutica], mas a mesma Constituição também diz que a Administração há de disciplinar. O que a Administração quer é não queimar medicamentos, como fizera no passado: comprou medicamento demais de uma determinada espécie, sem controle algum, e de menos de outra, daí o transtorno. Administração sem planejamento não é administração. (Processo n. 2002.288-7; acórdão 164.867, julgado em 11.06.02.)

Em recurso à ação civil pública impetrada pelo Ministério Público, em 2003, a Secretaria da Saúde assume que à "falta de recursos materiais e de pessoal especializado, não reúne condição de atender a toda a população, fazendo-se necessária a seleção dos pacientes a serem atendidos de forma prioritária". (Processo n. 2003.01.1.028 275-2, acórdão 203.001, julgado em 07.10.04.)

No mérito, esclarece que o poder público, para a consecução de seus fins, atua dentro de determinados limites orçamentários e de políticas públicas, não podendo o administrador dar vazão imediata a todas as necessidades da população, não havendo base de sustentação financeira programada para o atendimento de solicitações similares ao do presente feito. Esclarece que o conteúdo programático instituído pela Constituição Federal ao estabelecer o acesso público à saúde não pode ser entendido como o fornecimento instantâneo do tratamento médico a quem indistintamente dele necessite. (Processo $n$. 2005.01.1.029 123-2, acórdão 239.068, julgado em 12.12.05.)

A falta ou indisponibilidade do medicamento na rede e a complexidade dos procedimentos administrativos necessários para a aquisição também são frequentemente apresentados como razões para o descumprimento, pelo Estado, do seu dever de agir. Como eles também foram sistematicamente rebatidos e não prosperaram, tanto nas sentenças monocráticas quanto nos julgamentos de segunda instância, acabaram sendo pouco utilizados nos processo posteriores.

Com o aumento do número de ações pedindo medicamentos antirretrovirais inovadores que se verificou a partir de 2000, a alegação de que se tratava de medicamentos que não estavam disponíveis no mercado nacional e de que não tinham registro na Anvisa passou a ser feita com mais frequência, sem, no entanto, e da mesma forma, prosperar.

A Secretaria de Saúde voltou a empregar argumentos similares em suas defesas interlocutórias, apelações e agravos, principalmente em relação à apreciação de solicitações de dispensação de medicamentos experimentais 
para doenças raras. Os réus alegam que decisões favoráveis a esses casos representam grave lesão à saúde pública - porquanto obrigam o Estado, de forma ilegal e indiscriminada, ao fornecimento de um medicamento sem comprovação de eficácia, ou cujo uso é vedado, colocando em risco os pacientes que o utilizarem, dados os potenciais riscos de efeitos adversos ainda não totalmente pesquisados - e à ordem pública - já que dariam margem a outras decisões no mesmo sentido, com frontal infringência à legislação federal de regência.

$\mathrm{O}$ aviso de que determinadas sentenças "comprometiam o atendimento de dezenas de milhares de cidadãos pobres, portadores de moléstia grave" (Processo n. 1.684-0, de 1998, acórdão 132 349, julgado em 14.06.00); "constituem privilegiamento (sic) dos pacientes de AIDS em detrimento de outros" (Processo n. 2000.01.1.025 572-2, acórdão 140.533, julgado em 19.03.01); de que "as necessidades da comunidade são múltiplas e o atendimento a um determinado grupo de pessoas [referindo-se a quatro doentes com síndrome de Gaucher] colocaria em risco o atendimento dos demais" (Processo $\mathrm{n}$. 2000.00.2.000 838-8; acórdão 126 790, julgado em 27.03.00), é feito desde muito cedo, pelos réus. Ele, no entanto, não é escutado ou entendido.

Reiteradamente os réus fazem a defesa desse ponto de vista. Veja-se, como exemplo:

A sentença [em ação cautelar, que objetivava o fornecimento, pelo GDF, de medicamentos experimentais e sem registro na Anvisa para doentes de AIDS] viola o princípio da igualdade, pois os demais pacientes que não ingressarem em juízo não terão acesso a medicamentos importados e experimentais. (Processo n. 2001.01.1.054 820-8, acórdão 166.709, julgado em 30.09.02, recurso não provido.)

A sentença [em agravo à concessão de segurança para fornecimento de tratamento de segunda linha para hepatite $C]$ representa o sacrifício do bem estar geral em função de um jurisdicionado e uma agressão ao princípio da separação de poderes. (Processo n. 2003.00.2.000 543-2, acórdão 173.062, julgado em 31.03.03, agravo não provido.)

A sentença [concessiva, em ação cominatória para o fornecimento de medicamentos para tratamento de câncer de próstata] afronta o princípio da igualdade e da legalidade porque restringe o acesso aos medicamentos apenas aos jurisdicionados, em prejuízo dos demais. (Processo n. 2002.01.1.072 100-0, acórdão 179.011, julgado em 08.09.03, recurso não provido.)

O fornecimento ao autor de todo e qualquer medicamento objeto de prescrição médica constitui diferenciação desarrazoada para com os demais pacientes cadastrados junto ao serviço público de saúde, em patente violação ao princípio da igualdade. (Processo n. 2002.01.1.052 740-5, acórdão 191.073, julgado em 22.03.04, recurso não provido.) 
Também faz parte do conjunto de defesas dos réus a alegação de que tais sentenças constituem extrapolação da competência inerente ao Poder Judiciário e de que mandado de segurança não é o remédio constitucional adequado a amparar o direito pleiteado. A partir de 2002, os réus passam a alegar que elas constituem "invasão [do Poder Judiciário] na esfera de atuação meritória do administrador." (Projeto n. 2002.01.1.052 025-9, acórdão 188.299, julgado em 05.02.04.)

A partir do julgamento da primeira ação civil pública para concessão de medicamentos de alto custo para quatro pacientes portadores da síndrome de Gaucher, em 2000, a defesa da SESDF passou a trazer à consideração do Judiciário, nesses casos, o argumento de que se tratava da defesa de interesse individual e não difuso, daí decorrendo a ilegitimidade ativa do Ministério Público para agir:

(...) o manejo da presente ação civil pública por parte do Ministério Público tem por desiderato a proteção de direitos individuais de pessoas certas e determinadas, quais sejam os pacientes relacionados na petição inicial, e não a defesa de direitos difusos e individuais homogêneos, que é o que lhe autoriza o ordenamento jurídico, e para o que serve o instituto da ação civil pública. (Processo n. 2003.01.1.088 930-7; acórdão 231.342, julgado em 17.10.05.)

A tentativa de fazer juízes e desembargadores entenderem e aceitarem os conceitos de seleção de medicamentos e de protocolos clínico-terapêuticos, só mais tarde passou a fazer parte do conjunto de defesas dos réus para justificar o não-fornecimento de medicamentos não-previstos nos protocolos clínicos e listagens de medicamentos adotadas pelo SUS.

Os réus passaram a alegar "não haver direito líquido e certo do impetrante a adquirir, à custa do Poder Público, medicamento que não faz parte dos protocolos clínicos e diretrizes terapêuticas do Sistema Público de Saúde" (Processo n. 2005.00.2.011858-0; acórdão 239.793, julgado em 07.03.06) e a existência de outras opções terapêuticas de menor custo e boa eficácia. Sem justificativas técnicas consistentes - em verdade, sem um arrazoado que explicasse os conceitos e utilidade desses processos ${ }^{(35)}$ - a ideia teve dificuldade de prosperar, como se pode constatar na sentença abaixo citada:

Na ausência de prova produzida pelo impetrado de que o medicamento não é adequado ou que os medicamentos que possui são mais adequados, há direito líquido e certo do impetrante de adquirir o remédio pretendido. (Processo n. 2004.00.2.007563-2; acórdão 231.546, julgado em 29.03.05.)

(35) É interessante notar que a defesa do GDF e da Secretaria da Saúde é feita pela Procuradoria da Fazenda Pública, razão provável para a pobreza - em geral, ausência — de conteúdos técnicos de seus argumentos e pela dificuldade ou desinteresse em empregar ou explicar os conceitos e procedimentos técnicos envolvidos. 
A defesa de que pacientes de serviços privados, isto é, não-usuários de serviços da SESDF, não teriam direito à assistência farmacêutica no âmbito do sistema público se inaugura com o julgamento de processo, iniciado em 2002, que cuidava de um pleiteante portador de síndrome de Gaucher, que, por sinal, vinha sendo atendido num hospital público não pertencente à rede da SESDF (Hospital Sarah, da Fundação das Pioneiras Sociais). Apesar de, tanto quanto os outros argumentos dos réus, ter sido rejeitado, esse não deixou de ser usado por eles com frequência, em todo o período estudado.

Outros argumentos apresentados em defesa dos réus ou em recursos foram que o medicamento pleiteado não tinha eficácia cientificamente comprovada para aquela indicação e o fato da inexistência de periculum in mora.

\subsection{A conformação da jurisprudência}

O principal argumento que decide a favor dos pacientes-autores é o entendimento de que a prestação de assistência farmacêutica constitui materialização do direito constitucional à vida e à saúde, com base no que dispõem os arts. 5ำ 196 e 198 da Constituição Federal, além de imposição legal.

A imposição legal decorre de três normas, recorrentemente citadas: a Lei Orgânica da Saúde (LOS) (Lei n. 8.080, de 1990) (arts. 17 a 19), a Lei Orgânica do Distrito Federal (LODF) (arts. 204 e 207, II, XIV e XXIV) e a Lei n. 9.313, de 1996 (que torna obrigatória a assistência farmacêutica a portadores do HIV e doentes de AIDS).

Para os julgadores, esse é:

(...) direito positivo que exige prestações do Estado e que impõe aos entes públicos a realização de determinadas tarefas, de cujo cumprimento depende a própria realização do direito. (Processo $n$. 2002.00.2.005 331-3, acórdão 171.745, julgado em 25.03.03.)

Imperioso ao Estado garantir o fornecimento [do medicamento] em face da garantia constitucional do direito à vida e à saúde. (Processo $n$. 2003.00.2.000 543-2, acórdão 173.062, julgado em 31.03.03.)

A Administração Pública tem o dever inquestionável - e não a faculdade - de prestar assistência médica e de fornecer os medicamentos indispensáveis ao tratamento de paciente, sob pena de vir a lesar direito líquido e certo, principalmente aos carentes e portadores de moléstias graves, como a acometida pelo ora Apelado. (Processo n. 2002.01.1.101 094-2, acórdão 210.449, julgado em 13.12.04.)

Com efeito, o direito à vida e à saúde são direitos fundamentais garantidos a todas as pessoas, indistintamente, consoante se infere 
dos dispositivos supratranscritos [CF, arts. 6e 196; e LODF, art. 204, I, II, $\S \S 1^{\circ}$ e $2^{\circ}$, e art. 207, II]. Esses direitos, obrigatoriamente, devem ser garantidos pelo Estado, cabendo aos entes federados colocar à disposição de todos os meios necessários. Não o fazendo, certamente estarão violando aquele dever constitucional e poderão, inclusive, responder por omissão. A Lei n. 8.080/1990, que regulamenta o Sistema Único de Saúde, além de considerar a saúde como direito fundamental do ser humano, igualmente impõe ao Estado a obrigação de 'prover as condições indispensáveis ao seu pleno exercício’ (art. $2^{\circ}$ ). Dentro destes parâmetros legais, o direito reclamado pela Apelada não pode ser negado porque isto significaria desrespeitar os direitos fundamentais previstos na Carta Magna. (Processo n. 2004.01.1.052 457-0, acórdão 224.030, julgado em 27.06.05.)

Incide, pois, sobre o Poder Público, a indeclinável obrigação de fazer efetivos os serviços de saúde, incumbindo-Ihe promover medidas preventivas e de recuperação que tenham por finalidade viabilizar o que prescreve o art. 196 da Constituição Federal. É que o caráter fundamental do direito à saúde, garantido pela Constituição Federal, bem como pela Lei Orgânica do DF, impõe ao Estado o dever de prestação positiva de seus serviços. (Processo n. 2004.00.2.0063952, acórdão 241.184, julgado em 22.03.05.)

No entanto, fica também patente nos textos dos votos e decisões que, no entendimento dos julgadores, esse direito não é absoluto, isto é, é, em verdade, a situação de hipossuficiência financeira do paciente-autor que determina a concessão como se as pessoas que dispusessem de recursos próprios para a aquisição de medicamentos não fossem alcançadas pelo mesmo direito, fazendo perceber que, quando se trata de assistência farmacêutica, o direito constitucional e os princípios de universalidade e integralidade da atenção só se aplicam se o demandante não tiver recursos para prover o medicamento por contra própria. Poucas vezes se encontram, nos votos e decisões, afirmações de que "o direito à saúde deve ser assegurado, sem distinção, a todos os cidadãos" (Processo n. 2004.00.2.006 677-8, acórdão 215.115, julgado em 19.04.05.)

Juízes e desembargadores batem reiteradamente naquela tecla (grifos nossos):

[A Administração] terá de distribuir [medicamentos] àqueles que deles necessitam e que não desfrutam de condições financeiras para adquirilos. (Processo n. 2002.00.2.002 247-6, acórdão 164.261, julgado em 20.08.02.)

Cabe ao ente público cumprir seu papel e dar atendimento médico à população, oferecendo, àqueles que não possam arcar com seu tratamento, os medicamentos necessários, efetivando, assim, o que a 
LODF expressamente assegura. (Processo n. 2002.00.2.003 269-9, acórdão 166.279, julgado em 24.09.02.)

Em diversas oportunidades, este Egrégio Tribunal decidiu a respeito, sempre no sentido de forçar a Administração ao fornecimento dos remédios solicitados por aqueles que não têm condições de adquirilos por seus próprios meios. (Processo n. 2002.00.2.009 209-8, acórdão 185.791, julgado em 30.09.03.)

Não resta a menor dúvida que, ante termos candentes do art. 196 da CF/ 88, as três esferas de governo estão obrigadas a prestar assistência médica aos hipossuficientes, tanto assim, que veio a lume a Lei Federal 9.313/96, estabelecendo uma solidariedade passiva entre os mesmos. (Processo $n$. 2002.01.1.031 321-9, acórdão 185.400, julgado em 20.11.03.)

Cabe ressaltar que o tema em debate não é de todo novidade nos tribunais, sendo certo que a jurisprudência do Pretório Excelso tem firmado posicionamento no sentido de que o paciente hipossuficiente deve receber do Estado os medicamentos de que necessita. (Processo n. 2003.00.2.002 984-2, acórdão 187.718, julgado em 03.02.04.)

Esta Corte tem reconhecido que os portadores de moléstias graves, que não tenham disponibilidade financeira para custear o seu tratamento, têm o direito de receber gratuitamente do Estado os medicamentos de comprovada necessidade. (Processo $n$. 2003.01.1.065 766-3, acórdão 206.921, julgado em 22.11.04.)

Restando comprovado que o autor não pode arcar com as despesas sem privar-se dos recursos indispensáveis ao próprio sustento de sua família, o Estado está obrigado a fornecer de forma gratuita, os medicamentos destinados ao seu tratamento, sob o risco de afronta ao bem jurídico maximamente resguardado pelo ordenamento jurídico pátrio: a vida. (Processo n. 2004.01.1.075 727-5, acórdão 235.791, julgado em 16.01.06.)

Em decorrência, a Jurisprudência Interna Reiterada do TJDF não podia deixar de ser outra:

O Estado é obrigado a fornecer gratuitamente medicamentos necessários àqueles que não dispõem de recursos financeiros para custeá-los. (Relatório) É obrigatório o fornecimento de medicamentos pelo Estado, mesmo que de uso contínuo, à pessoa carente. (Entendimento do Tribunal)

Para a concessão de liminares, de segurança e de antecipação da tutela, a razão foi sempre a mesma: periculum in mora, isto é, a demora na obtenção do medicamento pleiteado - independente de parecer ou perícia, por sinal, sempre ausentes - é entendida como risco de dano irreparável ou de difícil reparação. 
Em relação aos argumentos dos réus, os julgadores - tanto os juízes em decisões monocráticas, nas iniciais, como os juízes e desembargadores nas decisões coletivas, de mérito e recursais - cuidaram de rebatê-los, um a um, conforme se analisa a seguir.

A responsabilidade do DF é firmada desde cedo, com base no princípio de descentralização do Sistema Único de Saúde, presente na Constituição Federal e na Lei Orgânica do Sistema, e em dispositivo sobre essa matéria na Lei Orgânica do Distrito Federal:

Não cabe denunciação à lide da União em se tratando de fornecimento de remédios a portadores de doença rara, vez que o sistema de saúde é descentralizado, com direção única em cada esfera de governo, prevendo a Lei Orgânica do Distrito Federal a sua competência para prestar assistência farmacêutica aos necessitados. (Processo $n$. 2000.00.2.000838-8, acórdão 126.790, julgado em 27.03.00.)

Os réus alegaram, com muita frequência e em todo o período estudado, a falta de competência e a ilegitimidade do GDF como parte passiva. Também esse argumento, no entanto, foi rebatido sistematicamente e sempre nas mesmas bases: a descentralização do SUS, insculpida nos arts. 17 a 18 da Lei Orgânica da Saúde; a obrigação legal de prestar assistência à saúde, inclusive farmacêutica, determinada pelo art. 207, incisos XIV e XXIV, da Lei Orgânica do Distrito Federal; e, posteriormente, as disposições da Lei n. 9.113, de 1996, em relação à assistência farmacêutica a doentes de AIDS.

Embora a União seja a gestora do SUS, não é a apelante [Secretaria da Saúde do DF] parte ilegítima para a causa, pois a Lei Orgânica do Distrito Federal estabelece o modo pelo qual são instrumentalizadas as atribuições do SUS no Distrito Federal, ou seja, por intermédio da Secretaria de Saúde, o que leva à conclusão de que o Distrito Federal é parte passiva legítima para a causa. (Processo n. 2005.01.1.0056638, acórdão 224.045, julgado em 08.08.05.)

Contra a alegação de que o direito não era devido porque o pleiteante não era cidadão do Distrito Federal ou aqui não tinha residência, foi dito sempre - e desde cedo - não ser esta uma condição legal, não cabendo prosperar. Com frequência, arregimentou-se, nesse sentido, o art. 204 da LODF que determina expressamente essa cobertura.

As alegações de extrapolação da competência inerente ao Poder Judiciário e de que as sentenças concessivas violam o princípio da separação dos poderes são enfrentadas e rebatidas recorrentemente pelos julgadores contrapondo-Ihes o disposto no art. 5ำ, inciso XXXV da Constituição Federal, segundo o qual a lei não excluirá da apreciação do Poder Judiciário lesão ou ameaça a direito.

Também não prospera a alegação do apelante no sentido de que a sentença recorrida viole o princípio da separação dos poderes, uma 
vez que o Administrador público não goza de liberdade para dar ou não cumprimento aos direitos fundamentais, pois, acima do princípio da legalidade previsto no art. 37 da Constituição Federal, está o princípio da constitucionalidade, que, no caso, impõe a imperiosa observância e a efetividade dos direitos à vida e à saúde; ademais, não se pode aceitar, como sugere o apelante, que haja um monopólio do Administrador quanto ao cumprimento dos preceptivos constitucionais, máxime os que estatuem direitos fundamentais. A propósito, se há uma esfera de poder que mais teve ampliadas as suas competências rumo à concretização das normas constitucionais, esta é a do Poder Judiciário. Havendo necessidade de concretização das normas constitucionais que vai além da mera previsão legal e alcança o caso concreto, o intérprete mais autorizado para a sua efetivação é o Poder Judiciário. (Processo n. 2002.01.1.052 025-9, acórdão 188.299, julgado em 05.02.04.)

Vê-se, desse modo, que, mais do que a simples positivação dos direitos sociais, recai sobre o Estado inafastável vínculo institucional consistente em conferir real efetividade a tais prerrogativas básicas, em ordem a permitir, às pessoas, nos casos de injustificável inadimplemento da obrigação estatal, que tenham elas acesso a um sistema organizado de garantias instrumentalmente vinculado à realização, por parte das entidades governamentais, da tarefa que lhes impôs a própria Constituição. (Processo n. 2002.01.1.091 335-9, acórdão 199.131, julgado em 05.08.04.)

A r. decisão impugnada [concessão de liminar em ação cominativa obrigando a Secretaria de Saúde do DF a fornecer medicamento não contemplado nos protocolos clínicos adotados] não está a invadir a seara discricionária da Administração, mas apenas impõe ao Estado o dever de assegurar a todos os cidadãos, indistintamente, o direito à saúde (art. $6^{\circ}$ e 196 da CF/88). Ademais, conforme preconiza o art. 207 da Lei Orgânica do Distrito Federal, compete ao Sistema Único de Saúde do DF prestar assistência farmacêutica e garantir o acesso da população aos medicamentos necessários à recuperação de sua saúde. (Processo n. 2005.00.2.000 355-5, acórdão 221.448, julgado em 06.06.05.)

Ao Judiciário cumpre velar pelo cumprimento dos preceitos constitucionais quando houver omissão por parte da Administração, acarretando lesão aos direitos fundamentais dos cidadãos, dentre eles, o direito à saúde, não havendo que se falar em invasão de competência. (Processo $n$. 2002.01.1.083 473-3, acórdão 237.596, julgado em 23.09.05.)

À alegação contra sentenças concessórias de segurança e à de que o mandado de segurança não é o remédio constitucional adequado a amparar o direito pleiteado, a corte de Brasília sempre se manifestou em contrário. 
Ver, a respeito os seguintes votos:

O mandado de segurança é via adequada para embasar o pleito da autora, eis que sustentado na negativa do DF em provê-la de medicamentos para o restabelecimento de sua saúde. (Processo $n$. 2002.01.1.052 025-9, acórdão 188.299, julgado em 05.02.04.)

(...) em que pese o esforço do apelante em demonstrar o desacerto da sentença guerreada, a meu sentir, esta mostra-se escorreita, eis que a ação civil pública intentada, ao viso de 'disponibilização, com urgência, de recursos financeiros para custear os medicamentos de alto custo para os pacientes do SUS/DF, após verificada a necessidade por indicação médica ou perícia', não contraria a previsão constitucional acerca da função institucional do Ministério Público, qual seja, de 'promover o inquérito civil e a ação civil pública, para a proteção do patrimônio público e social, do meio ambiente e de outros interesses difusos e coletivos' (art. 129, inciso III, da CF/88). Ademais, nos termos do art. 3o da Lei n. 7.347/85, que disciplina a ação civil pública, 'a ação civil poderá ter por objeto a condenação em dinheiro ou o cumprimento de obrigação de fazer ou não fazer'. Destarte, a despeito das ilações trazidas no recurso pelo Distrito Federal, em verdade, a questão principal tratada na presente hipótese é de direito indisponível (direito à saúde - art. 196, da CF/88), a importar, deste modo, aplicação da orientação jurisprudencial predominante de que detém o Ministério Público legitimidade ativa ad causam para propor Ação Civil Pública (...). O direito individual, nestes casos, tem extensa reverberação para que se alcance o interesse difuso, voltado ao direito à saúde e à vida atingindo uma gama de pessoas que se incluem numa categoria de desassistidas pelo Poder Público, um direito indisponível que o Estado não pode declinar ou desconsiderar por tratar-se de um dever inescusável. (Processo n. 2003.01.1.088 930-7, acórdão 231.342, julgado em 17.10.05.)

Uma defesa insistente do GDF e da Secretaria de Saúde - em especial, quando o pleito envolvia tratamentos com medicamentos inovadores, de segunda linha e de elevado custo - era a de que eles não estavam sendo disponibilizados porque não faziam parte das relações de medicamentos e protocolos clínico-terapêuticos adotados pelo Ministério da Saúde e pela Secretaria de Saúde - não fazia parte da "padronização", expressão adotada na linguagem dos autos.

Esse argumento encontrou aceitação limitada e transitória entre julgadores de ações movidas por pacientes de AIDS, nos anos iniciais do período estudado:

Não tem o Órgão Público como incluir entre os medicamentos a serem fornecidos a seus pacientes com AIDS outros que não estejam entre os 
listados pelo Ministério da Saúde. (Processo n. 2000.01.1.067510-0; acórdão 144.091, julgado em 25.06.01.)

(...) não se pode, sem cometer uma autêntica atrocidade técnica e jurídica, obrigar o Poder Público a entregar algo que, no estado das artes (tecnologia atual), sequer existe. (...) Mais parece que, se provido fosse semelhante pedido, a FHDF e o Distrito Federal sequer poderiam reunir comissões de avaliação de medicamentos, porque, a um simples lançamento de uma droga experimental, estaria o Estado, pela reprovável e temerária sentença condicional, pretendida pelo autor, obrigado a fornecer-lhe a droga. (Processo n. 1999.01.1.056322-5; acórdão 145.849, julgado em 27.08.01.)

A opinião, no entanto, cedo foi reformada, passando o Poder Judiciário local a entender tratar-se a seleção de medicamentos e a adoção de protocolos clínicos de "exigência de índole meramente administrativa" (Processo n. 2002.01.1.100 178-8, acórdão n. 194.078, julgado em 24.05.04); que "a limitação alegada traduz-se em negativa de dever constitucional" (Processo n. 1999.01.1.056 324-0, acórdão 153.317, julgado em 07.02.02); e que a prescrição médica deve prevalecer em qualquer caso.

Várias decisões a respeito desse tópico são reveladoras do pensamento e do entendimento dos juízes e desembargadores do TJDF.

Em relação ao primeiro aspecto (seleção de medicamentos como limitação do dever constitucional), ver:

A meu sentir, deve o Distrito Federal prover todo e qualquer medicamento que venha a ser receitado pelo médico do apelado (...), mesmo aqueles que hoje não [são] disponíveis pelo SUS. (Processo $n$. 1999.01.1.050 281-5; acórdão 130 705, julgado em 04.09.00.)

Ainda que a medicação pretendida não esteja padronizada pelo Ministério da Saúde para fornecimento gratuito aos doentes de AIDS, a comprovada necessidade do medicamento, prescrito por médico, impõe a condenação do Distrito Federal ao seu fornecimento, posto que não pode o dever do Estado limitar o direito à saúde, principalmente quando em risco a vida do paciente. (Processo n. 1999.01.1.056 324-0; acórdão 145 849, julgado em 27.08.01.)

Não merecem acolhida os argumentos lançados pelo DF de que os medicamentos solicitados pelo autor não integram a Portaria n. 874/97 do Ministério da Saúde, vez que, não possuindo o requerente condições econômicas que permitam adquirir os medicamentos necessários ao seu tratamento, não poderá o Estado abandoná-lo a própria sorte, omitindo-se em seu dever de assegurar a todos os cidadãos assistência social, bem como o direito à saúde. (Processo $n$. 2001.01.1.054 820-2, acórdão 166.709, julgado em 30.09.02.) 
(...) mostrando-se irrelevante não se encontrar o medicamento na lista dos medicamentos padronizados pelo Ministério da Saúde. (Processo n. 2000.01.1.074 934-2, acórdão 170.015, julgado em 30.09.02.)

Deve ser assegurado o fornecimento de todo e qualquer medicamento, inclusive aqueles não disponíveis na rede pública, mas que, no entanto, são indispensáveis ao tratamento do paciente. (Processo $n$. 2000.01.1.021 456-4, acórdão 172.250, julgado em 24.03.03) [ação ordinária com tutela pedindo medicamento inovador para a AIDS, ainda não selecionado e indisponível no mercado nacional].

A Carta Magna garante aos cidadãos acesso universal e igualitário às ações e serviços a fim de promover, proteger e recuperar a saúde, por ser ela direito de todos e dever do Estado. Não podem a União, os Estados, o Distrito Federal e os Municípios eximirem-se de fornecer medicamento a paciente que trata pela rede pública, ao argumento de que não consta da lista feita pelo Ministério da Saúde. (Processo $n$. 2001.01.1.054 820-2, acórdão 166.709, julgado em 30.06.02.)

(...) resta claro que o Distrito Federal tem a obrigação de fornecer os medicamentos pleiteados na inicial, bem como quaisquer outros que venham a ser necessários para o tratamento de saúde do impetrante, sem qualquer restrição, pois, sendo a saúde um direito fundamental, apenas à própria Carta Constitucional caberia impor limitações ao exercício de tal direito, o que não se verifica. [Contra-argumento ao fato de o medicamento pleiteado não constar da Rename nem da Relação de Medicamentos Excepcionais.] (Processo n. 2003.01.1.026 579-0, acórdão 215.419, julgado em 06.12.04.)

Não pode o Estado querer se eximir de sua responsabilidade constitucional, com argumentos de ordem burocrática. Não conceder o medicamento solicitado, apenas pelo fato de não estar o referido medicamento relacionado no rol dos medicamentos excepcionais, não conduz à conclusão de estar ele indisponível; demonstra, isto sim, como bem destacado em decisão que concedeu a liminar nestes autos, resistência do impetrado em fornecer a substância que a menor necessita para o seu tratamento. (Processo n. 2004.00.2.009 320-7, acórdão 214.038, julgado em 15.03.05.)

Por certo que a legislação infraconstitucional e demais atos normativos podem estabelecer diretrizes com vistas a racionalizar a prestação dos serviços de saúde pelos entes públicos. No entanto, carecem de legitimidade para limitar o direito à vida e à saúde, amplamente tutelados pela Constituição Federal. (Processo n. 2005.00.2.008 520-6, acórdão 235.405, julgado em 22.11.05.)

(...) Diante do princípio constitucional da dignidade da pessoa humana, tem o Distrito Federal a obrigação de fornecer os medicamentos 
necessários ao tratamento de saúde do cidadão, sem qualquer restrição relativa à lista elaborada pelo Ministério da Saúde ou prescrição por médicos da rede pública, pois, sendo a saúde um direito fundamental, apenas à própria Carta Constitucional caberia impor limitações ao exercício de tal direito, o que não se verifica. (Processo n. 2003.01.1.060 038-3, acórdão 258.867, julgado em 14.11.05.)

Quando passaram a crescer as alegações de falência terapêutica com o uso dos medicamentos selecionados, esse passou a ser um argumento de reforço às decisões dos julgadores em relação a esse aspecto:

A ordem constitucional vigente [referindo-se à Constituição Federal], em seu art. 196, consagra o direito à saúde como dever do Estado, que deverá, por meio de políticas sociais e econômicas, propiciar aos necessitados não 'qualquer tratamento', mas o tratamento mais adequado e eficaz, capaz de ofertar, ao enfermo, maior dignidade e menor sofrimento. (Processo n. 2004.00.2.006 395-2, acórdão 241.184, julgado em 22.03.05.)

As normas burocráticas não podem ser erguidas como óbice à obtenção de tratamento adequado e digno por parte do cidadão carente, em especial, quando comprovado que a medicação anteriormente aplicada não surte o efeito desejado, apresentando o paciente agravamento em seu quadro clínico. (Processo n. 2005.00.2.006 214-8, acórdão 238.054, julgado em 17.01.06.)

A ausência de explicitação dos alegados critérios técnicos e fundamentos dos protocolos clínicos e relações de medicamentos nas peças de defesa e recursais é mal recebida pelos julgadores, desfavorecendo a aceitação das teses dos réus:

Por fim, cumpre salientar que o agravante diz que a situação da recorrida não se enquadra nos critérios de inclusão no Protocolo Clínico do Ministério da Saúde, e que a recusa está pautada em critérios técnicos, mas sequer esclareceu na inicial quais seriam nem declinou os fundamentos adotados pela área técnica da Secretaria de Saúde para indeferir o pleito de fornecimento da medicação. (Processo $n$. 2005.00.2.000 355-5, acórdão 221.448, julgado em 06.06.05.)

Nesse contexto, foi inovador o entendimento do desembargador relator no julgamento de agravo de instrumento, com pedido de efeito suspensivo, interposto pelo Distrito Federal contra decisão monocrática que deferiu pedido de antecipação de tutela em ação cominatória de 2004 (Processo n. 2004.01.1.127 249-9), para que o réu/agravante fosse compelido a fornecer medicação não-selecionada, por período indeterminado, para tratamento da infecção pelo HIV.

No que tange à prescrição de medicamentos não constantes da lista padronizada pelo Ministério da Saúde, também entendo que não é 
possível que seja o Distrito Federal compelido a fornecê-los. 0 atendimento de toda e qualquer prescrição médica irá propiciar que todo e qualquer médico possa intentar tratamentos alternativos, de efetividade ainda não reconhecida, à semelhança da atividade de pesquisa. (Processo n. 2005.00.2.000 242-4; acórdão 225.798, julgado em 27.06.05.)

Em relação à proeminência da prescrição médica sobre a seleção ou o protocolo e, mesmo, sobre a ausência de registro do medicamento no País, ela se justifica, para os julgadores, por um de dois motivos: que o médico sabe tratar-se de medicamento existente no mercado e selecionado para utilização pelo SUS, ou que "é o médico que entende das necessidades de seu paciente".

Se o médico as receitou, em princípio, hão de existir no mercado nacional. Se não existirem, por certo haverão de ser substituídas por produtos que estejam ao alcance dos nacionais, ainda que importados. Esse é o lado técnico da responsabilidade médica. A decisão há que ser compreendida como sendo no sentido de que o Distrito Federal viabilize o atendimento do apelado, observando o receituário médico. (Processo n. 2000.01.1.025 572-2; acórdão 140 533, julgado em 19.03.01.)

Não prospera, também, o argumento de que os medicamentos ministrados ao autor limitem-se àqueles previstos na lista do Ministério da Saúde, comprovada pelo médico a necessidade do doente de medicação específica que venha a indicar, até porque as pesquisas nessa área são intensas, não se justificando privar o autor de utilizar uma medicação que possa melhorar sua saúde e sua qualidade de vida. (Processo n. 2001.01.1.054 820-2, acórdão 166.709, julgado em 30.06.02.)

Mesmo existindo normas restritivas quanto ao tratamento dos portadores de AIDS, cabe ao médico dizer da conveniência ou não de aplicar em seu paciente determinado procedimento, eis que problemas médicos não se solucionam de forma padronizada. Da doença de seu paciente, entende o médico que o assiste. (Processo n. 2001.01.1.054 820-2, acórdão 166.709, julgado em 30.09.02.)

No tocante ao fornecimento de medicamentos disponíveis no mercado brasileiro, excluindo-se os experimentais ou que não tenham sido aprovados pela Agência Nacional de Vigilância Sanitária, também não merece prosperar, pois, no presente caso, o medicamento prescrito e capaz de erradicar a hepatite $C$ é o Interferon Perguilado, de fabricação do Laboratório Schering Plough, devendo prevalecer a prescrição médica. (Processo n. 2002.01.1.033 737-7, acórdão 185.329, julgado em 03.11.03.) 
Se foi este o medicamento indicado pela médica, nós, que não somos versados em tal ciência, não devemos, por questão de ética, tecer considerações sobre os seus estudos. Se é este o medicamento necessário à saúde do paciente, não se pode deixar o paciente sem atendimento, simplesmente pelo fato daquele produto não fazer parte dos listados pelo Ministério da Saúde. A escusa somente seria válida se se tratasse de medicamento proibido pelo Ministério da Saúde. (Processo n. 2001.01.1.104096-3, acórdão 206.955, julgado em 25.10.04.)

Desde que prescrito o tratamento por profissionais que atendem aqueles que se valem do Sistema Único de Saúde - sabedores que são dos medicamentos possíveis de serem cedidos à população não pode haver recusa do Estado em fornecê-los ou questionamento acerca da necessidade ou não do seu uso para o tratamento indicado. (Processo n. 2004.00.2.009 320-7, acórdão 214.038, julgado em 15.03.05.)

Não cabe ao judiciário intervir na escolha do medicamento a ser ministrado, de forma a interferir no diagnóstico médico realizado por profissional capacitado que prescreveu o medicamento que entendeu necessário. (Processo n. 2002.01.1.085 369-3, acórdão 215.163, julgado em 18.04.05.)

Esse é, também, o entendimento do Ministério Público local:

Não são admissíveis os argumentos de que o medicamento não está incluído no programa de distribuição gratuita pelo sistema público de saúde e de que existem outras opções de tratamento com boa eficácia e menor custo. Não pode o Poder Judiciário se aventurar a escolher qual o melhor tratamento para uma paciente, interferindo em um diagnóstico que é essencialmente técnico e, inclusive, prescrito por um especialista da própria Secretaria de Saúde do DF [parecer da Procuradoria de Justiça]. (Processo n. 2004.00.2.007 562-1, acórdão 216.001, julgado em 15.03.05.)

Mesmo quando é reconhecida a ocorrência de erro do médico ao prescrever, tendem os julgadores a não penalizar o paciente:

Desde 1999, vigora a Lei n. 9.787, que introduziu modificações na Lei n. 6.360/76 e trouxe os conceitos de medicamento de referência, genérico e similar. Assim, o profissional já deveria ter receitado os medicamentos indicando o princípio ativo, mas, se assim não agiu, a paciente não pode ser apenada. (Processo n. 2003.01.1.096 067-5, acórdão 235.788, julgado em 12.12.05.)

A entrada em vigor da Lei n. 9.313, de 1996, que tornou obrigatória a distribuição gratuita de medicamentos para portadores do HIV e doentes de AIDS, ao mesmo tempo em que obriga a seleção, pelo Ministério da Saúde, dos medicamentos a serem disponibilizados, não alterou esse entendimento 
e o dispositivo que institui a seleção raramente foi empregado como argumento de defesa pelos réus e, menos ainda, considerado pelos julgadores, prevalecendo o entendimento de que a seleção consistia em mais uma "tratativa burocrática" ou "um óbice" a impedir a fruição de um direito positivo.

Ver, a respeito:

Compreendendo a força das normas essenciais da Constituição, não é de se admitir a limitação do fornecimento de medicamentos à relação padronizada para cada estágio evolutivo da infecção e da doença determinada pelo Ministério da Saúde (Lei n. 9.313/96, concretizada pela Portaria do Ministério da Saúde n. 874/97). Decerto que, para a racionalização da prestação do serviço, essa medida administrativa é importante, já que é útil para a maioria dos casos. Entretanto, haverá situações diferenciadas que não podem ficar desprotegidas pelo Poder Público como in casu. Cada paciente precisa ser avaliado individualmente e, segundo o seu estado clínico, haverá de ser medicado adequadamente, sem ficar limitado ao convencimento pelo Ministério da Saúde ou qualquer outra lei que venha a vedar-lhe o direito à vida. (Processo n. 1999.01.1.068 577-0, acórdão 166.475, julgado em 03.09.01.)

Pela peculiaridade de cada caso e em face da urgência, há que se afastar a delimitação de medicamentos constante na Lei n. 9.313/96. (Processo n. 2001.01.1.054820-8; acórdão 166.709, julgado em 30.09.02.)

Dúvida, portanto, inexiste de que, em hipóteses que tais, compete ao Estado suprir a necessidade do cidadão, fornecendo-Ihe o medicamento de que necessita. Se não o faz, embora sob o pretexto de disciplinar a distribuição e planejar o suprimento, força convir que não cumpre o preceito fundamental estabelecido pelo legislador constituinte. Nem mesmo a regulamentação federal [portarias do Secretário de Assistência á Saúde do Ministério da Saúde] tem, a meu juízo, relevância bastante, porquanto, estando em colidência com o preceito da Lei Maior, a este devem ceder. (Processo n. 2002.00.2.000292-2, acórdão 161.858, julgado em 11.06.02.)

Ainda que a medicação pretendida não esteja padronizada pelo Ministério da Saúde para fornecimento gratuito aos doentes de AIDS, a comprovada necessidade do medicamento, prescrito por médico, impõe a condenação do DF ao seu fornecimento, posto que não pode o dever do Estado limitar o direito à saúde, principalmente quando em risco a vida do paciente. (Processo n. 2001.01.1.054 820-2, acórdão 166.709, julgado em 30.06.02.)

Portarias [que regulamentam a Lei $n$. 9.313/96] são óbices à fruição de direitos constitucionais. (Processo n. 2001.01.1.045 242-0, acórdão 178.641, julgado em 17.02.03.) 
O direito constitucional à saúde não se submete à limitação infraconstitucional ditada pela Lei n. 9.313/96, pois a função do Estado é de proteger e recuperar a saúde dos cidadãos e a efetividade dessa meta não pode ser comprometida por alegações de dificuldades orçamentárias ou tratativas burocráticas. (Processo n. 2000.01.1.021 456-4, acórdão 172.250, julgado em 24.03.03.)

A incidência da legislação distrital ou mesmo daquela de origem federal (Lei n. 9.313/96), somente tem pertinência quando a medicação fornecida pela Saúde Pública produzir efeitos no organismo do paciente, no mesmo grau da medicação que foi prescrita pelo facultativo particular, sendo que, neste diapasão, a contraprova estava a cargo do Estado, e se nada restou combatido neste sentido, não há como obrigar o apelado a tomar remédio que não seja aquele estabelecido pelo seu médico. (Processo n. 2001.01.1.054 821-9, acórdão 192.032, julgado em 18.03.04.)

A existência de regulamentação mais delimitada do direito à saúde, como sucede com a obrigatoriedade do fornecimento de medicamentos a portadores do vírus HIV, por força da Lei n. 9.313/96, embora diminua a indeterminação e a incerteza do conteúdo das normas de direitos fundamentais, não impede que o magistrado, no pleno exercício de sua tarefa de concretização dos programas normativos constitucionais, dê efetividade e delimite-os na situação concreta, dentro dos limites e possibilidades jurídicas e fáticas do caso. (Processo n. 2004.01.1.021 055-4, acórdão 209.789, julgado em 24.02.05.)

Pela peculiaridade de cada caso e em face da sua urgência, há que se afastar a delimitação no fornecimento de medicamentos constante na Lei n. 9.313/96. (...) Prejuízos iriam ter os recorridos se não Ihes for procedente a ação em tela, haja vista que estarão sendo usurpados no direito constitucional à saúde, com a cumplicidade do Poder Judiciário. (Processo n. 2004.01.1.056 063-6, acórdão 228.130, julgado em 26.09.05.)

O entendimento da Portaria n. 14, de 2001 (anteriormente citada e que regulamentou, no âmbito da SESDF, a dispensação de medicamentos de dispensação em caráter excepcional) não foi diferente.

Apesar da defesa da normativa pelos réus, feita em julgamento de mérito, segundo a qual "não se pode asseverar que a exigência contida na Portaria n. 14 (...) encontra-se em rota de colisão com a norma constitucional. Pelo contrário, o disciplinamento da matéria há de ser entendido como salutar para os fins de planejamento da atividade estatal", ela não encontra apoio. A contestação contra-argumenta que:

Nesse contexto de ideias [CF 196; LODF 204 e 207], ressai que formalidades de cunho burocrático não podem ser concebidas, ainda que sob a roupagem da legalidade, para obstaculizar a efetividade de tão 
relevantes direitos subjetivos-públicos, especialmente se considerarmos que o Estado não pode assumir comportamentos que afetem a existência do ser humano (...) Diante desse cenário [periculum in mora], a liquidez e certeza do direito da impetrante ressaem incontestes, mormente porque recebem respaldo dos princípios e garantias de ordem constitucional, que, em muito, sobrelevam a meras formalidades de cunho burocrático ditadas por atos normativos, sabidamente de hierarquia inferior. (Processo n. 2002.00.2.000 289-7, acórdão 166.890, julgado em 11.06.02.)

Ver também:

Não há necessidade de a impetrante demonstrar que é cadastrada no Programa para que seu direito seja reconhecido. Basta a prova de que é portadora da doença, reforçada pela receita prescrita por seu médico particular. (...) A meu ver, o acesso universal e igualitário à saúde não pode esbarrar na prática burocrática imposta pela Portaria. (Processo n. 2002.00.2.000 286-5, acórdão 164.866, julgado em 25.06.02.)

A observância literal da mencionada Portaria equivale à indiscutível restrição de direito fundamental, que não pode ser admitida; a não ser que se considere que esse direito não passa de uma promessa vã, uma declaração de princípios irresponsável. Nem mesmo a regulamentação federal [portarias do Ministério da Saúde, expedidas pelo Secretário de Assistência à Saúde] tem, a meu juízo, relevância bastante, porquanto, estando em colidência com o preceito da Lei Maior, a este devem ceder. (Processo n. 2002.00.2.002 247-6, acórdão 164.261, julgado em 20.08.02.)

Eventual ausência de formalidade burocrática não pode obstar a concessão da medida buscada, posto não retirar a gravidade da situação. (...) [Direito constitucional / legal] inclui o fornecimento de medicamentos, quer no âmbito dos estoques de seus estabelecimentos, quer por meio de aquisição junto ao comércio. (Processo $n$. 2001.01.1.054 820-2, acórdão 166.709, julgado em 30.09.02.)

O procedimento de mudança de critérios com os receituários coloca 0 paciente em uma fila, sujeito a várias situações, para comprar o remédio, para pegar nova receita com o médico da Fundação, vez que não se aceita mais a do médico particular. Esse transtorno burocrático chega a ser perigoso, podendo ser fatal para o doente. (Processo $n$. 2002.00.2.002 247-6, acórdão 164.261, julgado em 20.08.02.)

Não é pequena a proporção de autores que não são usuários da SESDF, isto é, que tiveram o medicamento prescrito por médico ou serviço não pertencente à rede daquela secretaria, e que, ainda assim, pleiteiam seu fornecimento pelo sistema público. Essa situação nunca foi aceita pela Secretaria de Saúde, sob alegação de não ser sua obrigação prestar assistência farmacêutica nesses casos. 
O entendimento do TJDF, no entanto, é distinto, ainda que não unânime. As posições a seguir exemplificadas constituíram votos vencidos:

Quero deixar assentado que esses medicamentos ['medicamentos futuros que vierem a ser ministrados'] continuam sendo garantidos nos termos da sentença e do meu voto, contudo, se ministrados por médicos integrantes da medicina pública, e não por médicos particulares (...) É somente esse reparo que, por enquanto, devo fazer ao voto: o medicamento garantido é aquele passado por médico da rede pública. (Processo n. 2000.01.1.025 572, acórdão 140 533, julgado em 19.03.01.)

[A 2 $2^{a}$ Turma Cível] entendeu ser legítima sua pretensão no sentido de que a condenação ao fornecimento do medicamento deverá se limitar àqueles prescritos pelos médicos da rede pública, impedindo, deste modo, que o Distrito Federal seja obrigado a fornecer todo e qualquer medicamento, a qualquer preço, alguns até ainda em fase experimental, prescritos por médicos particulares. (Processo n. 2002.00.2.009 0021, acórdão 172.316, julgado em 24.03.03.)

Essa opinião, no entanto, é contestada e vencida, prevalecendo o entendimento que considera o ato "desarrazoado" por conflitar com o direito constitucional à vida e à saúde. Ver:

Receio que nem sempre o médico oficial terá liberdade e imparcialidade suficientes para, se for o caso, prescrever um remédio até fora daqueles constantes na tabela do Ministério da Saúde. Penso que, ao restringirmos o receituário ao médico oficial, poderíamos, na verdade, estar limitando a prescrição de um remédio apenas àqueles autorizados pela administração pública. (Processo n. 2000.01.1.025 572, acórdão 140 533, julgado em 19.03.01.)

Não há necessidade de a impetrante demonstrar que é cadastrada no Programa para que seu direito seja reconhecido. Basta a prova de que é portadora da doença, reforçada pela receita prescrita por seu médico particular. (Processo n. 2002.00.2.000 286-5, acórdão 164.866, julgado em 25.06.02.)

A portaria coloca em dúvida a capacidade e honestidade dos médicos profissionais não vinculados ao SUS sem apresentar qualquer justificativa para desmerecer o respectivo trabalho. (Processo $n$. 2002.01.1.055 192-2, acórdão 173.657, julgado em 24.03.03.)

Exigência desarrazoada [ser usuário do SUS, o medicamento ter sido prescrito por médico do SUS] frente aos imperativos constitucionais (CF, 196) e da LODF. (Processo n. 2002.01.1.029 445-5, acórdão 174.856, julgado em 14.04.03.)

Descabido também o pleiteado pelo recorrente [GDF] no sentido de que os medicamentos sejam prescritos por médico da rede pública, 
pois, conforme consta dos autos, o ora apelado [paciente] sofre de moléstia que exige tratamento especializado, identificada por profissional de saúde capacitado, compete ao Estado fornecer o medicamento prescrito. (Processo n. 2002.01.1.003 737-7, acórdão 185.329, julgado em 03.11.03.)

A aquisição de medicamento excessivamente oneroso e, ao mesmo tempo, essencial à vida do cidadão não pode estar condicionada à receita prescrita por médico integrante do Sistema Único de Saúde. $O$ desatendimento a uma formalidade burocrática não tem o condão de obstar os direitos à vida e à saúde, contemplados e guarnecidos pela Constituição Federal, inclusive como direitos fundamentais. (Processo n. 2004.00.2.002 388-5, acórdão 202.130, julgado em 28.09.04.)

(...) a própria LODF estabelece que, preferencialmente, as ações e serviços de saúde devem ser prestados pela rede pública, não havendo como a prescrição dos medicamentos por médico que não o da rede pública se tornar um óbice à garantia à vida conferida constitucionalmente a cada cidadão. Condicionar o direito pleiteado pelo autor a tal exigência implicaria em ofensa às disposições constitucionais e à lei distrital, razão pela qual não se pode acolher as justificativas do apelante [SESDF] de que assim não procedendo, estar-se-ia violando o princípio da igualdade com relação aos demais cidadãos que também necessitam de ajuda do Estado para a aquisição de medicamentos. (...) O fornecimento gratuito de medicamentos não deve limitar-se àqueles prescritos pelos médicos da rede pública de saúde, pois, caso contrário, estará se criando restrição ao direito constitucional à saúde. (Processo n. 2005.01.1.023 107-5, acórdão 228.608, julgado em 03.10.05.)

(...) o acesso às ações e serviços de saúde implementados pelo Estado deve ser universal e igualitário, não podendo obrigar o cidadão a se submeter à rede pública para tratamento médico como condição imprescindível ao fornecimento de medicamentos. (Processo $n$. 2004.01.1.075 727-5, acórdão 235.791, julgado em 16.01.06.)

Mais adiante, ainda que seja reconhecida a racionalidade da medida, as condições de sua implementação frente à insuficiência da assistência médica na rede pública é vista como uma condição de risco à saúde do paciente-autor da ação e, por isso, o argumento é recusado:

Assim mostra-se desarrazoada a exigência de que fornecimento do medicamento esteja condicionado à prescrição por médicos do Sistema Único de Saúde, pois, inelutavelmente, renderá danos irreversíveis ao impetrante. Tal reclame seria pertinente se a população do Distrito Federal pudesse contar com atendimento qualificado e oportuno, que correspondesse às suas necessidades. (Processo n. 2004.00.2.002 388-5, acórdão 202.130, julgado em 28.09.04.) 
Lamentavelmente, a realidade que nos espelha é a de que o atendimento pelo sistema público de saúde é lentíssimo, precário, tanto em recursos humanos quanto materiais, o que obriga muitos cidadãos que, aliás, pagam a contribuição compulsória respectiva, a buscarem o atendimento médico particular - não por opção, cumpre ressaltar, mas por necessidade - lembrando, inclusive, que nem todos os que assim agem detêm poder aquisitivo para tanto. Não obstante a isso, nos momentos cruciais, é comum tirar-se das verbas destinadas às despesas necessárias, para não se ter que sujeitar às intempéries dos hospitais públicos. (Processo n. 2002.01.1.069 918-4, acórdão 217.760, julgado em 25.04.05.)

A alegação de ausência de comprovação da indicação ou de benefício do medicamento pleiteado passou a ser arregimentada pelos réus a partir de meados do período estudado e também não recebeu guarida nos julgamentos de mérito:

Não pode o Poder Judiciário se aventurar a escolher qual o melhor tratamento para uma paciente, interferindo em um diagnóstico que é essencialmente técnico, prescrito por um especialista da área médica. (...) A pairar sobre tais aspectos, exsurge a prevalência do preceito constitucional de direito à saúde, sustentando, sem qualquer sombra de dúvida, o direito líquido e certo de 'acesso universal igualitário às ações e serviços para a sua promoção, proteção e recuperação' (art. 196/CF), não se perdendo de vista que o conceito de acesso universal igualitário à saúde carrega em seu bojo as conquistas e avanços disponibilizados pela ciência médica. (Processo n. 2004.00.2.007 5479, acórdão 208.959, julgado em 14.12.04.)

$A$ incerteza dos resultados advindos do tratamento, bem como o seu custo-benefício [alto custo, reações adversas importantes] e a ausência de risco de morte da Impetrante, alegada pela apontada autoridade coatora, não têm o condão de obstar a concessão do medicamento, à consideração do risco de danos posteriores irreparáveis à saúde da paciente na sua estatura final. (Processo n. 2004.00.2.009 228-1, acórdão 225.810, julgado em 02.08.05.) [Em julgamento de mandado de segurança impetrado contra o Secretário de Saúde do DF para obtenção de medicamento não-selecionado nos protocolos clínicos adotados para tratamento de nanismo.]

Na ausência de prova produzida pelo impetrado de que o medicamento não é adequado ou que os medicamentos que possui são mais adequados, há direito líquido e certo do impetrante de adquirir o remédio pretendido. (Processo n. 2004.00.2.007 563-2, acórdão 231.546, julgado em 29.03.05.) [Em julgamento de mandado de segurança impetrado contra o Secretário de Saúde do DF para obtenção de 
medicamento não-selecionado nos protocolos clínicos adotados para tratamento de osteoporose.]

A possibilidade de intercambialidade do medicamento de marca pleiteado por um genérico também não é aceita pelo tribunal, em razão da "insuficiência de provas de sua eficácia".

Também não goza de aceitabilidade a impugnação à marca comercial do medicamento constante da sentença (Interferon), vez que a suposição da possibilidade de aquisição de genéricos com a mesma fórmula química ativa demanda a produção de provas de sua eficiência no tratamento da doença de que padece o autor, provas que não foram carreadas pelo apelante. (Processo n. 2002.01.1.044 967-0, acórdão 201.227, julgado em 16.08.04.)

O medicamento reclamado pela impetrante nesta sede recursal não objetiva permitir-lhe, apenas, uma maior comodidade em seu tratamento. O laudo médico, colacionado aos autos, sinaliza para uma resposta curativa e terapêutica 'comprovadamente mais eficaz', além de propiciar ao paciente uma redução dos efeitos colaterais. A substituição do medicamento anteriormente utilizado não representa mero capricho da impetrante, mas se apresenta como condição de sobrevivência diante da ineficácia da terapêutica tradicional. (...) In casu, não havendo prova documental de que o remédio fornecido gratuitamente pela administração pública tenha a mesma aplicação médica que o prescrito ao impetrante, fica evidenciado o seu direito líquido e certo de receber do Estado o remédio pretendido. (Processo n. 2005.00.2.006214-8, acórdão 238.054, julgado em 17.01.06.)

A indisponibilidade do medicamento na rede pública jamais foi aceita como argumento ou defesa. $O$ fato é entendido como negligência que apena o usuário e contraria princípio constitucional:

Indisponibilidade de medicamento na rede pública fere o princípio constitucional da continuidade dos serviços públicos. (Processo $n$. 2003.00.2.005 655-3, acórdão 180.905, julgado em 14.10.03.)

Eventuais exigências burocráticas não podem afastar a responsabilidade do Estado, sob pena de se negar direito constitucionalmente previsto, possibilitando a evolução da doença, impondo sérios prejuízos ao agravado que não dispõe de condições para arcar com o alto custo do tratamento. (Processo n. 2002.01.1.033 737-7, acórdão 185.329, julgado em 03.11.03.)

Não pode o Distrito Federal esquivar-se da obrigação legalmente imposta, ao argumento de que não há previsão orçamentária para a compra dos medicamentos e que ainda não foi realizada licitação para 
escolher o fornecedor dos produtos. Com efeito, não pode ser o beneficiário do sistema de saúde apenado pela negligência do Poder Público. (Processo n. 2002.01.1.063 874-6, acórdão 184 431, julgado em 24.11.03.)

O direito à saúde e, portanto, à vida, devem ser garantidos de forma eficaz e concreta. Não se pode olvidar que há entraves burocráticos na maioria das vezes de difícil solução para o administrador. Contudo, os problemas administrativos podem até ser de difícil resolução, mas não podem configurar barreira intransponível a ponto de se lesionar direitos de tão grande quilate como o direito à saúde e à vida. (Processo $n$. 2005.00.2.000 386-7, acórdão 214.203, julgado em 25.04.05.)

Não havendo estoque do medicamento, o Distrito Federal deverá suportar as despesas para adquiri-lo de imediato, a fim de evitar danos maiores à saúde do paciente. (...) Não é admissível o argumento de indisponibilidade, ainda que pontual, do medicamento na rede pública de saúde, pois fere o princípio constitucional da continuidade dos serviços públicos. (Processo n. 2005.01.1.005 663-8, acórdão 224.045, julgado em 08.08.05.)

O reconhecimento de que o suprimento depende de transferência de recursos federais não é aceito como justificativa para que o Distrito Federal deixe de cumprir o que está "no âmbito de sua competência material", segundo dispõem a Constituição Federal e a Lei Orgânica do Distrito Federal, mas ao contrário, caracteriza, para os julgadores, incompetência administrativa.

A simples argumentação de que para tanto se faz necessário o repasse de recursos não afasta a constatação de que se faz necessária efetiva previsão de tal suprimento, de forma a atender a demanda que pode ser mensurada pelo governo local, que por certo dispõe de dados e servidores aptos a empreender tal serviço de evidente utilidade pública. (Processo n. 2002.01.1.091 335-9, acórdão julgado em 05.08.04.)

Nesse mesmo sentido, é também frequentemente contra-argumentado que não incorre em ilegalidade o administrador que promova a aquisição emergencial dos medicamentos, com dispensabilidade de licitação, em casos de "urgência de atendimento de situação que ocasionar prejuízo ou comprometer a segurança de pessoas", segundo previsão da Lei de Licitações.

A alegação de que o medicamento pleiteado não era registrado na Agência Nacional de Vigilância Sanitária (ANVISA) ou é experimental e, portanto, não se encontra internalizado no mercado nacional ou não pode ser aqui comercializado, não foi considerada razão relevante para o Judiciário local.

Dito isto [CF 196; LODF 207, XXIV], cinge-se à questão sobre a impossibilidade do cumprimento, pelo agravante, do disposto na $r$. 
decisão agravada, eis que o medicamento fornecido aos agravados não se encontra registrado na Anvisa, o que impossibilita sua importação. Pelos documentos juntados aos autos, verifico que os agravados recebiam [o medicamento] 'a título de experiência' efetuada pelo [médico particular], medicamento este que fora doado pelo laboratório Genzyme Corporation. Informam os agravados, na inicial da ação proposta, que iniciaram o tratamento específico para a doença de Fabry e que, após o período de um ano, ainda necessitam de 144 doses do referido medicamento, oportunidade em que requereram junto à Secretaria de Estado de Saúde do DF a continuidade de seu fornecimento, uma vez que é o único disponível no mercado capaz de amenizar os efeitos da patologia referida. (...) Ora, os argumentos aduzidos pelo agravante (...) não devem prosperar. Primeiro, pelo fato de que, se o medicamento (...) não é registrado pela Anvisa, (...), deve o agravante, apenas e tão somente, solicitar aos seus órgãos competentes o cumprimento da decisão. Sequer consta dos autos prova de que lhe foi negada a importação do referido medicamento, ou de que o mesmo não se encontra registrado pela Anvisa. Se iniciaram o tratamento $e$, ao que me parece, vêm ocasionando resultados satisfatórios aos agravados, sua interrupção abrupta deve ser refutada. (...) Dessa forma, (...) resta claro que o Distrito Federal tem a obrigação de fornecer o medicamento pleiteado na inicial daquela ação, pois, sendo a saúde um direito fundamental, apenas à própria Constituição Federal caberia impor limitações ao exercício de tal direito, o que não se verifica. (Processo n. 2004.00.2.001770-8, acórdão 193.672, julgado em 24.05.04.)

A alegação de impossibilidade jurídica e material, alegada pelos réus, não é considerada pelos julgadores:

Sendo prescrita a substância por médico responsável pelo tratamento do paciente, máxime se integrante da rede pública de saúde, ainda que não registrado o fármaco perante a Agência Nacional de Vigilância Sanitária, faz-se necessária a sua importação diante da finalidade terapêutica indicada. (Processo n. 2004.01.1.011071-5, acórdão 212.073, julgado em 21.03.05.)

No ano de 2004, no julgamento de ação cominatória de autoria de um grupo de pacientes portadores de doença de Fabry, que pleiteavam a dispensação de medicamento não-registrado na Anvisa e, portanto, ausente do mercado nacional, o juiz, em decisão monocrática, indeferiu - pela primeira vez - a solicitação, sendo esta decisão confirmada em acórdão julgado no mesmo ano, não dando provimento ao recurso dos autores:

Se não há interesse da empresa fabricante em exportá-lo, bem como da empresa representante em registrar e comercializar esse produto, entendo que não há como compelir o Distrito Federal a promover a 
aquisição do medicamento solicitado. (Processo n. 2004.00.2.006 3972, acórdão 202.068, julgado em 01.10.04.)

Tendo, no entanto, os autores recorrido da sentença, ela veio a ser reformada, acatando o parecer do Ministério Público de que "estar-se-ia condicionando a efetividade de uma garantia constitucional a procedimentos burocráticos".

As alegações de ameaça de lesão à ordem por ir de encontro à legislação que proíbe a importação, prescrição e uso de medicamento nãoregistrado pelo organismo de vigilância sanitária e de risco à saúde do paciente são afastadas:

Diante da gravidade do caso em concreto, não antevejo, no simples fato de inexistir registro do medicamento no Ministério da Saúde, ameaça de lesão à ordem ou à saúde pública. Tampouco resta ameaçada, por isso, a saúde da impetrante, haja vista que a decisão condiciona o fornecimento à prescrição médica, e pela prescrição do medicamento, responde o médico requisitante. (Processo n. 2004.01.1.011 071-5, acórdão 212.073, julgado em 21.03.05.)

Ainda que tenham sido dadas sentenças no sentido do fornecimento de "outros medicamentos que venham a ser receitados", além dos pleiteados na ação, ou de mantê-los "enquanto o paciente deles precisar", acabou prevalecendo jurisprudência em sentido contrário:

Não se pode onerar a administração pública com obrigações futuras e incertas, além daquelas legalmente estabelecidas. (Processo $n$. 1999.01.1.061 120-9; acórdão 135 175, julgado em 11.12.00.)

Parece-me quase impossível para o Estado fornecer remédios 'que venham a ser receitados aos autores em prescrição médica futura', pois existe uma verba destinada ao atendimento desses casos, e o Estado tem outras prioridades que devem ser atendidas, não podendo ficar à mercê do receituário dos médicos que não integram o SUS. (Processo n. 2000.01.1.067 510-0; acórdão 144 091, julgado em 25.06.01.)

Não se pode, sem cometer uma autêntica atrocidade técnica e jurídica, obrigar o Poder Público a entregar algo que, no atual estado das artes (tecnologia atual) sequer existe. (...) Não há sentenças condicionais e, no caso, o autor insiste em obter o pedido não só condicional, mas também temerário de obrigar o Estado a Ihe fornecer 'qualquer medicamento futuro'. Mais parece que, se provido fosse semelhante pedido, a SESDF e o Distrito Federal sequer poderiam reunir comissões de avaliação de medicamentos, porque a um simples lançamento de uma droga experimental, estaria o Estado, pela reprovável e temerária sentença condicional, pretendida pelo autor, obrigado a fornecer-lhe a 
droga." [Conclui que é licito obrigar o fornecimento e a substituição de medicamentos, "desde que estejam disponíveis no mercado e não em fase experimental, prescritos por médicos especialistas".] (Processo $n$. 1999.01.1.056 322-5; acórdão n. 145 849, julgado em 27.08.01.)

Constitui verdadeira norma específica concreta, em branco, traduzindo-se em delegação de atividade jurisdicional, haja vista que nem mesmo prevê qualquer forma de liquidação judicial dessa condenação indeterminada. (Processo n. 2000.01.1.042 285-5; acórdão 152 863, julgado em 25.02.02.)

A apreciação quanto à necessidade continuada e indefinida da medicação prescrita deve permanecer sob o crivo da autoridade judiciária, com determinações exatas na quantidade que a parte ré está obrigada a prestar, evitando-se, assim, a ruptura na atividade de prestação jurisdicional. (...) O atendimento de toda e qualquer prescrição médica irá propiciar que todo e qualquer médico possa intentar tratamentos alternativos, de efetividade ainda não reconhecida, à semelhança da atividade de pesquisa. (Processo n. 2005.00.2.000 2424; acórdão 225.798, julgado em 27.06.05.)

A defesa do réu baseada em que o pleito jurisdicionado responde a interesse individual e não difuso foi apresentada, pela primeira vez, contra ação civil pública que pedia a entrega de medicamentos de alto custo a quatro pacientes portadores da síndrome de Gaucher, em 2000, passando a ser utilizada em outras lides. Esse, no entanto, não tem sido o entendimento da Corte do TJDF:

O fato de uma moléstia vir a ser caracterizada como rara, que atinge um número bastante restrito de pessoas, não transmuta sua natureza de interesse difuso para individual, pois, para além do universo das personalidades envolvidas, remanesce o interesse relativo a ações $e$ serviços de saúde, que é de todos, não se desfigurando, destarte, a legitimidade do Ministério Público. (Processo n. 2000.00.2.000 838-8; acórdão 126 790, julgado em 27.03.00.)

Não se trata meramente de privilegiar um interesse material e específico do jurisdicionado em prejuízo à coletividade, mas de garantir a própria vida de um de seus componentes que, em ultima ratio, é interesse coletivo, bem como resguardar a continuidade do serviço público de assistência à saúde, que não pode ficar apenas sujeita de forma absoluta à discricionariedade administrativa, sobretudo em razão da possibilidade de ocorrência do desvio de finalidade ou abuso de poder. (Processo n. 2003.00.2.000 543-2, acórdão 173.062, julgado em 13.03.03.)

Não há ofensa à isonomia, pelo atendimento à pretensão autoral, eis que remonta à Antiguidade, mais especificamente a Aristóteles, a ideia 
de que isonomia não significa tratamento cegamente igual para todos - antes, representa a equiparação dos desiguais, a fim de garantir-seIhes a igualdade de condições tanto para a fruição de direitos como na imposição de deveres relativos ao grupamento social. Ora, se o autor possui necessidade de atendimento especial, identificada por profissional de saúde capacitado para tanto, é forçoso reconhecer que, numa consideração decorrente do princípio da isonomia, deve ser atendido em sua necessidade específica. A isonomia não se presta a socializar as mazelas decorrentes da má administração, como pretende a defesa, mas em fazer exigir o devido atendimento pelos poderes públicos às necessidades de todos, indistintamente. (...) Pois bem, a negativa de fornecimento de medicamento devidamente prescrito por médico ao paciente que dele necessite refoge à razoabilidade e à proporcionalidade, impondo sacrifício desmesurado do administrado, na tutela de supostos interesses públicos não devidamente configurados. (...) (Processo n. 2002.01.1.091 335-9, acórdão julgado em 05.08.04.)

Em ação civil pública impetrada em 2004 pelo Ministério Público contra o Distrito Federal objetivando "a disponibilização, com urgência, de recursos financeiros para o custeio dos medicamentos necessários à quimioterapia no Hospital de Base do Distrito Federal, e os devidos reparos nos aparelhos de radioterapia, ou, se for o caso, a aquisição de novas máquinas", a decisão inicial do juiz monocrático foi de "ausência de legitimidade ativa do Ministério Público para exigir o cumprimento da obrigação de fazer em prol de pessoas devidamente identificadas na ação". Julgamento posterior, no entanto, reformou a decisão:

É de simples constatação o fato de que o direito à saúde, indissociável do próprio direito à vida, é não somente um direito individual indisponível, mas também um direito difuso inerente a todo e qualquer ser humano, indistintamente. No caso dos autos, a ação civil pública foi proposta (...) para a proteção de direitos difusos, a fim de ver efetivamente garantido a todos os cidadãos do Distrito Federal, o acesso universal e igualitário à saúde. Tal pleito engloba, de forma plena, a defesa dos direitos individuais indisponíveis das pessoas elencadas no pedido. (Processo $n$. 2004.00.2.000 475-5, acórdão 203.751, julgado em 23.08.04.)

O impacto orçamentário e financeiro da decisão judicial é apresentado pelos réus como alegação frequente e também sistematicamente desconsiderada pelos julgadores com base em dois contra-argumentos: o de que limitações orçamentárias não podem suplantar direitos constitucionais e o de que não ficou demonstrado, pelos réus, em seus recursos, o "risco ou dano à ordem, à saúde, à segurança ou à economia pública":

É certo que o judiciário não pode ordenar ao poder executivo que efetue despesas não previstas ou acima do que foi previsto na lei orçamentária. No caso em debate [autor portador de síndrome de 
Gaucher que pleiteava fornecimento de medicamento de elevado custo], não se pretende invadir a seara de discricionariedade da administração ou da atividade própria do poder legislativo. O que se impõe no caso vertente é a observância do princípio da continuidade da prestação dos serviços públicos essenciais, nos quais se inclui, claramente, a prestação de assistência à saúde. (Processo n. 2000.00.2.000 838-8, acórdão 126 790, julgado em 27.03.00.)

A escassez orçamentária e a necessidade de procedimentos administrativos para a aquisição não podem suplantar o direito à vida e à saúde. (Processo n. 1999.01.1.056 324-0; acórdão 153 317, julgado em 07.02.02.)

Dúvida, portanto, inexiste de que, em hipóteses que tais, compete ao Estado suprir necessidade do cidadão, fornecendo-Ihe o medicamento de que necessita. Se não o faz, embora sob o pretexto de disciplinar a distribuição e planejar o suprimento, força convir que não cumpre o preceito fundamental estabelecido pelo legislador constituinte. (Processo n. 2002.00.2.002247-6; acórdão 164.261, julgado em 20.08.02.)

O direito ora guerreado vincula-se diretamente ao próprio direito à vida do autor, o qual poderia ser comprometido caso não Ihe fosse propiciado o tratamento recomendado. (...) Se o custo é elevado, cabe ao Executivo rever a forma de administrar seus recursos e fazer valer o direito protegido constitucionalmente. (Processo n. 2001.01.1.048 045-0, acórdão 199 795, julgado em 06.09.04.)

Com efeito, (...) por certo que o Judiciário não pode obrigar o poder público a efetuar gastos não previstos pelo orçamento. No entanto, o Estado tem o dever constitucional de preservar o direito à vida e à saúde, reservando em seu orçamento recursos para o cumprimento de seu elevado objetivo. (Processo n. 2004.01.1.066 049-0, acórdão 214.192, julgado em 02.05.05.)

Mostra-se desarrazoada a alegação de que existem limitações orçamentárias, pois, inelutavelmente, não se pode obstar o exercício dos direitos à vida e à saúde, contemplados e guarnecidos pela Constituição Federal, a simples argumentação de insuficiência de recursos financeiros. (Processo n. 2002.01.1.069 918-4, acórdão 271.760, julgado em 25.04.05.)

A insuficiência de recursos é interpretada por juízes e desembargadores como incompetência administrativa e desinteresse em agir, por parte do gestor público:

Não socorre ao recorrente a alegação da ausência de recursos materiais e humanos, pois, tais fatos demonstram tão somente a falta de seriedade com que o assunto é tratado pelos entes responsáveis 
pela manutenção do sistema de saúde pública. Cabe à Administração dar à questão a importância devida, adotando as medidas necessárias ao cumprimento da ordem judicial. (Processo n. 2003.01.1.028 275-2, acórdão 203.001, julgado em 07.10.04.)

O ônus que possui o Distrito Federal de prestar assistência médica à parte foi imposto pela Constituição Federal e reafirmado pela Lei Orgânica do Distrito Federal. Portanto, nem a ausência de medicamentos disponíveis nem, tampouco, a falta de recursos para adquiri-los podem ser utilizados como argumento para que este ente federativo se exima do cumprimento de sua obrigação. Com muita propriedade ressaltou 0 MM. Juiz na r. sentença, (...) que "(...) se o custo é elevado, cabe ao Executivo rever a forma de administrar seus recursos e fazer valer direito protegido em sede constitucional". (Processo n. 2004.01.1.069 975-9, acórdão 226.807, julgado em 19.09.05.)

Sobre o comprometimento de outras ações programadas em decorrência de sentenças que se pretendia reformar - em especial aquelas concessórias da obrigação de fornecer medicamentos de alto custo - a posição do Judiciário foi no sentido de não valorizar o argumento:

É de tudo louvável o combate à malária, bem assim à desnutrição. 0 que é certo, absolutamente certo, é que as vítimas dessas duas últimas deficiências de saúde são tratáveis até com medicamentos caseiros ou, quiçá, apanhados no balcão dos raizeiros ou numa boa horta. Destarte, não recebo com muita boa vontade esses argumentos do apelante como causa de pedir para a desconstituição da decisão judicial, que manda, nos termos da Constituição Federal e das leis, fornecer medicamento indispensável à manutenção da vida aos portadores do HIV. (Processo n. 2000.01.1.025 572-2; acórdão 140 533, julgado em 19.03.01.)

É certo, que se devem tomar em consideração, na tarefa de concretização dos programas normativos, as reservas do financeiramente possível, dentro dos limites que o orçamento enseja. Contudo, nenhuma demonstração inequívoca se apresenta nos autos de que a concessão da ordem venha a provocar danos à ordem, à saúde, à segurança ou à economia pública, tanto que nenhuma provocação nesse sentido foi promovida pelo apelante, consoante as regras que constam da Lei Federal n. 4.348/66. (Processo $n$. 2002.01.1.052 025-9, acórdão 188.299, julgado em 05.02.03.)

Inegavelmente, a Administração Pública tem a obrigação de, no desempenho de suas funções, dar aos administrados tratamento isonômico. Todavia, a pretensão do impetrante não traz, como consequência, a quebra da igualdade prevista na Constituição Federal, uma vez que, incumbe ao Estado o fornecimento da medicação que for prescrita pelo médico, e, assim, caso outros pacientes necessitem fazer uso do mesmo fármaco, a eles também deve ser assegurado o 
fornecimento, inclusive, se preciso for, pela via judicial. (Processo $n$. 2004.01.1.052 065-7, acórdão 206.996, julgado em 03.02.05.)

$\mathrm{Na}$ medida em que todas as decisões do TJDF, no período estudado, concederam os medicamentos pleiteados pelo autor da ação, fica evidente que a escassez de recursos e o comprometimento de outras ações programadas não constituem argumentos aceitáveis para impedir ou limitar a concessão, o que é similar ao descrito por Wang em estudo sobre a jurisprudência do Supremo Tribunal Federal.(36)

\section{CONSIDERAÇÕES FINAIS}

A denominada judicialização da política de assistência farmacêutica vigente no Distrito Federal se inicia com ações por medicamentos antirretrovirais, impetradas por pacientes de AIDS contra a SESDF, nos anos finais da década de 1990. Foi o julgamento desses casos que estabeleceu e conformou a jurisprudência do TJDF sobre a matéria, que veio a se consolidar no período estudado com muito poucas reformulações quando, a partir de 2001, a judicialização alcançou um número crescente e diversificado de outros medicamentos incluindo, principalmente, medicamentos contemplados nas relações oficiais, para a atenção básica e de média complexidade.

Nesse sentido, foram cristalizados, na jurisprudência do TJDF, alguns entendimentos entre os quais se destacam:

1. O reconhecimento de que a prestação de assistência farmacêutica pelo Estado constitui materialização do direito constitucional à vida e à saúde, além de imposição legal, e, portanto, depende da concretização de políticas públicas, tornando-se a omissão do Estado em implementá-las uma violação desses direitos. A assistência farmacêutica é concebida como um direito jurisdicionalmente tutelável do qual decorre o poder do cidadão de exigir, do Estado, a prestação.

2. A relativização desse direito, que é determinado, também, pela situação de hipossuficiência do autor-paciente, isto é, a jurisprudência deixa implícito que as pessoas que dispõem de recursos próprios para a aquisição de medicamentos não são, necessariamente, objeto desse direito, fazendo perceber que, quando se trata de assistência farmacêutica, o direito constitucional só se aplica se o demandante não tiver recursos para prover o

(36) WANG, Daniel Wei Liang. Escassez de recursos, custos diretos e reserva do possível na jurisprudência do Supremo Tribunal Federal. [S.I.]: Berkeley Program in Law \& Economics, Latin American and Caribbean Law and Economics Association (Alacde), 2007. Disponível em: <http:// repositories.cdlib.org/bple/alacde/050207-16/>. Acessado em: 17 out. 2007. 
medicamento por contra própria(37). Isso, no entanto, não impediu que a totalidade dos pedidos fosse concedida.

3. A dificuldade dos julgadores de lidarem com conceitos técnicos como seleção de medicamentos (denominada "padronização", nos textos dos acórdãos estudados), protocolo clínico, intercambialidade e vigilância sanitária, e a incapacidade ou desinteresse dos réus em explicá-los, conferem baixíssimo ou ausente conteúdo técnico às peças processuais. Como resultado, importantes instrumentos técnicos de gestão da política (relações/ seleção de medicamentos, intercambialidade, protocolos clínicos, registro de medicamentos) são entendidos por juízes e desembargadores como meros entraves burocráticos e mecanismos de resistência do gestor ao seu dever de agir.

4. O estabelecimento da precedência da prescrição médica sobre quaisquer outros argumentos, mesmo quando ilegal (como no caso da prescrição de medicamentos experimentais fora de protocolos de pesquisa e de medicamentos sem registro no sistema de vigilância sanitária do país) ou sem respaldo técnico (sem comprovação de eficácia ou segurança e em indicação terapêutica ou dosagem não-aprovadas pela vigilância sanitária).

5. A ausência de solicitações de perícias e provas, tanto de parte dos réus como dos julgadores.

6. A não-consideração ou relativização de disposições legais frente à prevalência de disposições constitucionais que instituem o direito público subjetivo à saúde - e no seu âmbito, o acesso ao medicamento - como prerrogativa jurídica indisponível. Por se tratarem de normas infraconstitucionais, os dispositivos da Lei n. 9.313, de 1996, (que obriga a distribuição gratuita de medicamentos a portadores do HIV e doentes de AIDS) que instituem a seleção ("padronização") dos medicamentos alcançados pela obrigatoriedade, não são considerados pelos julgadores — que a entendem como mero procedimento burocrático. Da mesma forma e pela mesma razão, a confrontação a dispositivos legais que proíbem a importação, a prescrição e o uso de medicamentos não-registrados pelo Sistema Nacional de Vigilância Sanitária é relativizada nas decisões.

Esse fato permite antever que a edição de novas normas legais que busquem delimitar o direito, o acesso ou a extensão da assistência farmacêutica a ser prestada no âmbito do Sistema Único de Saúde, muito provavelmente, não surtirá o efeito desejado de reduzir o número e o objeto das ações judiciais contra o sistema de saúde, mesmo com a institucionalização de processos técnicos similares aos citados.

(37) É interessante notar que, nos relatórios dos primeiros acórdãos sobre a matéria, na década de 90 , pode-se observar que alguns julgadores concebem a assistência farmacêutica como uma ação de assistência social e não de saúde. 
7. Por fim, é possível verificar que as consequências econômicas e distributivas das decisões em ações de medicamentos não são preocupação do TJDF que sempre entendeu que esses argumentos não são aceitáveis quando se trata do direito constitucional à saúde. Os custos envolvidos para a efetivação dos direitos pleiteados, no caso da assistência farmacêutica, não são considerados elementos relevantes para o julgamento da matéria pelo TJDF que, reiteradamente, manifestou-se no sentido de que limitações orçamentárias não podem suplantar direitos constitucionais - interpretando que tais limitações representam ou incompetência administrativa ou desinteresse em agir, por parte do gestor público. As decisões desconsideram, também, o risco de comprometimento de outras ações programadas em decorrência de sentenças concessivas.

\section{REFERÊNCIAS BIBLIOGRÁFICAS}

CÂMARA DOS DEPUTADOS. Comissão Parlamentar de Inquérito com a finalidade de investigar denúncias de irregularidades na prestação de serviços por empresas e instituições privadas de planos de saúde. Relatório final. Brasília, nov. 2003.

CASAGRANDE, Cássio. Ministério Público, ação civil pública e a judicialização da política - perspectivas para o seu estudo. Boletim Científico da Escola Superior do Ministério Público da União, Brasília, a. 1, n. 3, p. 21-34, abr./jun. 2002.

CONSELHO NACIONAL DE SECRETÁRIOS DE SAÚDE. Carta de Porto Alegre. Relatório do Seminário 'O SUS, o Judiciário e o Acesso aos Medicamentos Excepcionais' (Porto Alegre, 9-10 de julho de 2004). In: CONASS. Nota Técnica 13/2005. Brasília, jul. 2005.

Diagnóstico do Programa de Medicamentos de Dispensação em Caráter Excepcional nas Secretarias Estaduais de Saúde. In: CONASS. Assistência farmacêutica: medicamentos de dispensação em caráter excepcional. Brasília, 2004. (Série CONASS Documenta, n. 5).

Para entender a Gestão do Programa de Medicamentos de Dispensação em Caráter Excepcional. Brasília, 2004. (Série CONASS Documenta, n. 3).

DELDUQUE, Maria Célia; OLIVEIRA, Mariana Siqueira de Carvalho. O papel do Ministério Público no campo do Direito e Saúde. In: MINISTÉRIO DA SAÚDE. Fundação Oswaldo Cruz. Questões de direito sanitário. Brasília: Ed. do Ministério da Saúde, 2006.

FUNDAÇÃO OSWALDO CRUZ (FIOCRUZ). Pesquisa Mundial de Saúde: Brasil 2003. Rio de Janeiro, 2004. 
INSTITUTO BRASILEIRO DE GEOGRAFIA E ESTATístICA. Pesquisa de Orçamento Familiar. Rio de Janeiro, 2003.

MARQUES, Silvia Badim; DALLARI, Sueli Gandolfi. Garantia do direito social à assistência farmacêutica no Estado de São Paulo. Revista de Saúde Pública, São Paulo, v. 41, n. 1, p. 101-107, 2007.

MESSEDER, Ana Márcia; OSORIO-DE-CASTRO, Claudia Garcia Serpa; LUIZA, Vera Lucia. Mandados judiciais como ferramenta para garantia do acesso a medicamentos: a experiência do Estado do Rio de Janeiro, Brasil. Cadernos de Saúde Pública, Rio de Janeiro, v. 21, n. 2, p. 525-534, mar./abr. 2005.

MINISTÉRIO DA SAÚDE. Conselho Nacional de Saúde. Relatório Final da $1^{a}$ Conferência Nacional de Medicamentos e Assistência Farmacêutica. Brasília, 2005.

Relação Nacional de Medicamentos Essenciais (RENAME). 3. ed. Brasília, 2002. (Série B. Textos Básicos de Saúde).

NUNES JÚNIOR, Amandino Teixeira. Considerações sobre a Judicialização da Política no Brasil. Cadernos Aslegis (Brasília), v. 8, n. 29, p. 33-39, maio/ dez. 2006.

ORGANIZAÇÃO MUNDIAL DA SAÚDE (OMS). The World Health Report, 2006. Genebra, 2006.

SOUZA JÚNIOR, Antônio Humberto. O Supremo Tribunal Federal e as questões políticas. Porto Alegre: Síntese, 2004.

TATE, Neal; VALLINDER, Torbjörn (Orgs.). The global expansion of Judicial Power. New York: New York University Press, 1995.

TRIBUNAL DE CONTAS DA UNIÃO. Avaliação do TCU sobre a Ação Assistência Financeira para Aquisição e Distribuição de Medicamentos Excepcionais. Brasília: TCU, 2005. (Sumários Executivos, 23). Disponível em: <www.tcu.gov.br/avaliacaodeprogramasdegoverno>.

VIEIRA, Fabiola Sulpino; ZUCCHI, Paola. Distorções causadas pelas ações judiciais à política de medicamentos no Brasil. Revista de Saúde Pública, São Paulo, v. 41, n. 2, p. 212-222, 2007.

WANG, Daniel Wei Liang. Escassez de recursos, custos diretos e reserva do possível na jurisprudência do Supremo Tribunal Federal. [S.I.]: Berkeley Program in Law \& Economics, Latin American and Caribbean Law and Economics Association (Alacde), 2007. Disponível em: <http://repositories.cdlib.org/bple/ alacde/050207-16/>. Acessado em: 17 out. 2007.

YEPES, Rodrigo Uprimny. A judicialização da política na Colômbia: casos, potencialidades e risco. Sur Revista Internacional de Direitos Humanos (São Paulo), a. 4, n. 6, p. 53-70, 2007. 